\title{
Ante la cámara lúcida de la memoria. Divisiones y uniones fotográficas entre descendientes de víctimas y victimarios de la guerra de España -y su amplio marco medial y transcultural
}

\author{
Rike Bolte \\ Universidad del Norte, Barranquilla
}

\begin{abstract}
Resumen:
Este artículo propone una mirada sobre el extenso y a la vez denso entramado de trabajos por la memoria postdictatorial articulada entre Argentina y España. Partiendo de sus implicaciones conflictivas más estudiadas, vuelca su mirada sobre los novísimos aportes tanto en términos generacionales como mediales, y en distintas cohortes descendientes de víctimas y victimarios. El interés por la transferibilidad de los esfuerzos mnemónicos de las sociedades postdictatoriales lleva a un objeto medial específico: la fotografía. La pregunta que orienta entonces el ensayo es cuáles serían las posibilidades de este arte (lúcido) de participar de un narrative que busque hacer visibles aspectos de una memoria a la que se la han inscrito anatomías de la división ideológica. Así, se analiza un encuentro entre descendientes de víctimas y victimarios de la guerra de España y su registro fotográfico realizado por José Aymá, y se verifica si este trabajo puede ser comparado con una obra genuinamente transcultural del argentino Gustavo Germano. Esta puesta en relación de dos trabajos fotográficos que enfocan los estatus de unión/separación, se verá enmarcada por una serie de reflexiones referidas a las (meto-)mnemografías transculturales que se expresan en el espacio de los nuevos medios.
\end{abstract}

Palabras clave: memoria histórica transcultural, Argentina, España, víctimas y victimarios, José Aymá, Gustavo Germano, nuevas generaciones mnemónicas

\begin{abstract}
:
The present essay proposes a perspective on the very complex network of post-dictatorial 'memory work' articulated between Argentina and Spain, including not only the most conflictive zones — that have been widely studied - but primarily the newest contributions, both with regard to generational patterns and to media communication strategies. The essay's focus lies on photography, seeing this form of expression as a 'lucid art' and as an important element when it comes to creating a narrative that helps to make visible certain aspects of a memory that has been ideologically divided. In the light of this, the essay analyses an encounter between descendants of victims and victimizers of the Spanish war, portrayed by José Aymá. The intention is to determine if the work of this Spanish photographer could be compared with another, genuinely transcultural work by the argentine photographer Gustavo Germano. Beyond this 'dialogue' of photographic portraits that focus the status of union versus separation, the essay suggests a number of reflections on the transcultural meta-mnemographies that are to be found in the new media space.
\end{abstract}

Keywords: transcultural historical memory, Argentine, Spain, victims and perpetrators, José Aymá, Gustavo Germano, new mnemonic generations 
En los estudios de la memoria —alentados por trabajos icónicos como las de Walter Benjamin y nutridos por los planteamientos teóricos de las ciencias culturales y los estudios postcoloniales - solemos prestar especial atención a las memorias menores, no verificadas y por lo tanto tampoco estilizadas por la historiografía y la memoria hegemónica. Sin embargo, como lo demuestra el texto de Lauge Hansen en esta publicación, a lo largo de la diversificación de este campo de estudios se ha empezado a tomar en consideración la memoria de los representantes de una "zona grigia" (Primo Levi) $)^{1}$ : la de los perpetradores o Mitläufer, simpatizantes. En el presente ensayo nos interesaremos por el enfrentamiento mnemónico y mnémico ${ }^{2}$ entre los descendientes de los victimarios y los de sus víctimas. Es decir, descendientes de ambos bandos, quienes en el presente pueden a su vez ser, o no, representantes de los bandos ideológicos opuestos de sus antecesores. Continuando con la metáfora de los colores, quedaría por definir qué zona cromática le correspondería a este encuentro; sin embargo, nos abstendremos de ahondar en esta parte de las metáforas visuales.

Más bien se tratará de situar el encuentro mnemónico y mnémico en cuestión, que tuvo lugar en ocasión del 80 aniversario de un capítulo conflictivo por antonomasia de la 'memoria histórica's española: la guerra de España y la consiguiente dictadura de

1 Véase al respecto la entrada en página del Centro Internazionale di Studi Primo Levi: http://www.primolevi.it/Web/Italiano/Contenuti/Auschwitz/105_Sulla_\%22zona_grigia\%22 (2 julio 2018).

${ }^{2}$ El término 'mnémico' se refiere aquí a los aspectos de una memoria 'orgánica', sin soporte 'mnemónico', es decir sin recursos directos relacionados con la mnemotecnia o las políticas de la memoria.

${ }^{3}$ Nos parece pertinente indicar la observación de Abril Trigo de que la noción de 'memoria histórica' merece ser usada con cierto cuidado, ya que se trataría, en el fondo, de un “oxímoron” (Trigo 403). La tensión del concepto reside en la identificación de la memoria -proceso y capacidad (vis y ars) de una cultura vital- con la historia, que según Maurice Halbwachs, a quien Trigo se refiere, comienza allí donde la memoria colectiva empieza a desmoronarse. Por supuesto, estas observaciones deben ir acompañadas por un número de aclaraciones acerca de cómo definir 'historia', así como paralelamente deben calibrarse las nociones de la memoria colectiva y de la política de la memoria (politics of memory) o política de la historia (Geschichtspolitike) -más otros conceptos confluyentes. Las formulaciones y definiciones pueden ser muy distintas, como la planteada por Halbwachs en su obra póstuma La memoire collective (1950), en donde esta es definida como la memoria de acontecimientos no vividos directamente, sino transmitidos por otros medios; a saber, como un registro intermedio entre la memoria viva y las esquematizaciones de la disciplina histórica. Las adjetivaciones de la memoria se refieren, entre otras cosas, al grado de evolución de la sociedad (o comunidad) en cuestión. Abril Trigo subraya que la comunidad se caracteriza por la memoria colectiva (de carácter oral), siendo la memoria histórica una característica de la sociedad. En este ensayo, por motivos de espacio, los términos que identifican los distintos grados y formas de una memoria colectiva relacionada a la elaboración de un pasado histórico, marcado por la violencia, se usarán de forma implícita. El término 'memoria histórica' será utilizado porque dejarlo de lado significaría establecer una distancia terminológica artificiosa frente al objeto de estudio. De todas formas valga anotar que en España, la noción de 'memoria histórica' es un concepto historiográfico, de relevancia para los estudios de la memoria, por supuesto, pero ante todo está impregnado de significado político, e ideológico. Más allá de estos aspectos, sobre los cuales este ensayo volverá más adelante, en España se ha debatido el término-concepto, por ejemplo por parte de Santos Juliá o Francisco Ayala; entre los cuales el primero no solamente ha puesto en duda que un individuo sea capaz de recordar algo, más allá de la propia experiencia (Ruiz Torres 68), sino además ha expresado la sospecha que la implementación de una "memoria histórica" podría implicar el dominio de un "imperio de la memoria" (Juliá). También Ruiz Torres se expresa de forma escéptica sobre el concepto-término (68, 72). Cf. además Mercedes Yusta Rodrigo, Bernecker y Pichler respectivamente, quienes serán citados más adelante. Como última observación: Es altamente significativa la entrada sobre la 'memoria histórica' en la página hispanohablante de Wikipedia. El rubro "Memoria histórica por país" reúne tres casos, que prima facie 
Franco, desde un encuadre medial claramente acotado, a saber: un registro basado en los dispositivos de visualización y visibilización que brinda la fotografía.

La fotografía será considerada como una de las ramas mediales del vasto entramado de trabajos (y luchas) de y por la 'memoria histórica' articulada entre Argentina y España. Esta 'cooperación de memorias', que puede ser llamada transcultural, ha sido estudiada desde las ciencias sociales por Cuesta Bustillo y Elsemann.

De modo que ciertos procedimientos mnemotécnicos y meta-mnémicos, así como también meta-mediales específicos, que verificamos en la fotografía argentina consagrada a la historia de la violencia y la desaparición forzada bajo la última dictadura cívico-militar iniciada en 1976 (Bolte, Gegen(-)Abwesenheiten; Bolte, "Imágenes"; Bolte, "Memoria"), serán transferidos a otro dispositivo estético, en el cual los/las descendientes de los generales que estuvieran enfrentados en las trincheras de la guerra de España, son invitados a ocupar su puesto en una escena medial.

En el marco de este contexto comparativo, nuestro ensayo prestará atención además a un nuevo capítulo de la memoria en Argentina: la aparición de descendientes de victimarios, que alzan la voz logrando un eco medial bastante nutrido. Teniendo en cuenta que entendemos al trabajo de la memoria como un ejercicio determinado por múltiples coyunturas (transgeneracionales, transculturales y transmediales), nos preguntamos si este novísimo aporte a las memorias postdictatoriales argentinas poseerá cualidades transferibles al caso español que nos interesa.

Ante el campo interferencial que supone el escenario de un encuentro de memorias paradigmáticamente antagónicas (colectivas en parte, individuales en otra) como el que focalizaremos, se revela el valor multiplicador de las interacciones, contaminaciones y compenetraciones transculturales y transmediales que se manifiestan en la lucha mnemónica, que se sigue manteniendo viva en España. Incontables son los actos de traducción de saberes empíricos, teóricos y simbólicos sobre el pasado entre este país y otros, en los cuales también se sigue combatiendo por la memoria — por ejemplo, Argentina-.

La obra del fotógrafo argentino Gustavo Germano, a la cual recurriremos para preparar y además ampliar la 'lectura' de los retratos fotográficos de los y las descendientes de los generales de la guerra de España, realizados por José Aymá, da fe de esta dimensión, como también lo hace, por ejemplo, un capítulo literario-forense compartido entre España y Argentina: el traslado de la causa (Federico García) Lorca a Argentina.

Tras la autorización de parte del juez (fiscal) español Baltasar Garzón ${ }^{4}$ para la exhumación de las fosas comunes a las que habrían ido a parar las víctimas de los enfrentamientos durante la Guerra Civil y la sublevación franquista en 1936, el proyecto de ubicar los restos del poeta andaluz, termina en un infructuoso "peinado" del terreno en cuestión (Martín-Arroyo). La prensa opinó en su momento que la historia de Lorca

parecerían estar ordenados por orden alfabético, Argentina figurando en primer lugar. Sin embargo este caso es seguido por el de España; y el tercero y último es Colombia.

${ }^{4}$ Baltasar Garzón se ha manifestado últimamente acerca del reciente y 'rectualizador' caso de desaparición forzada en Argentina (el de Santiago Maldonado). Además, Garzón ha creado una fundación dedicada a promover los derechos humanos y la lucha contra la impunidad. La noción de 'justicia universal' es sustancial para esta iniciativa -en el caso de la fosa de Lorca, la ARMH (Asociación para la Recuperación de la Memoria Histórica) recurrirá justamente a ella. Cf. http://baltasargarzon.org/baltasar-garzon-en-curso-ucm/en-otros-paises/argentina/ (2 julio 2018). 
se 're-escribiría' en aras de la polémica por la 'memoria histórica' y que los resultados arqueológicos, es decir científicos, de 2009 podrían figurar como un punto cero de esa historia (El País 2009). ${ }^{5}$

$\mathrm{El}$ intento de un reajuste del relato de la muerte de Lorca sirve como ejemplo de las implicancias narrativistas de la historiografía y de los comunicados que la prensa emite en su nombre. Pero también da cuenta de un 'embrollo jurídico'. Pues en España, "los jueces no quieren encargarse de las fosas del franquismo - como en cambio sí hacen los jueces argentinos con las víctimas de la dictadura—, y menos aún, después de ver al único juez que quiso hacerlo [Garzón, R.B.] sentado en un banquillo por ello." (Junquera) En este contexto, la causa Lorca es desplazada a Argentina, haciendo patente entonces el fenómeno del sustancial ir y venir de los saberes (tanto empíricos como teóricos), que se da en el trabajo de las memorias postdictatoriales.

Elsemann por ejemplo entiende a la causa Lorca como ejemplo de la falta de definición jurídica y simbólica respecto a las víctimas del franquismo, porque las voces de quienes en España acusaban a Garzón de alterador, se habían conjurado en que Lorca no habría sido ejecutado, sino que habría simplemente desaparecido. Como subraya la autora, estos agentes de (o contra) la 'memoria histórica' española desdibujan el carácter sistemático de la praxis violenta y aniquiladora que representa la desaparición forzada y revelan, además, su relación con una estrategia aplicada también en Argentina en el marco del Terrorismo de Estado, sólo que en Argentina esta estrategia habría sido definida jurídicamente con más rigor y elaborada de forma modélica (Elsemann 218-219). ${ }^{6}$ Ya en este aspecto negador de la causa Lorca se encuentra - ex negativoun eslabón que enlaza la lucha por la memoria histórica española con la cultura de la memoria y la elaboración del pasado reciente de la violencia en Argentina. Pero todavía habrá de darse un paso decisivo en el camino de las alianzas entre activistas de la memoria de ambos países, cuando en primavera del año 2016, la Asociación para la Recuperación de la Memoria Histórica (ARMH) en España toma la decisión de poner el caso en manos de la juez argentina María Servini ${ }^{7}$ — hasta que en otoño de 2016 el caso retorna a España, donde ahora continúa su curso-

Con esto, el presente ensayo abre su recorrido hacia varios apartados consagrados a los aspectos mediales y generacionales de la transmisión de los trabajos por la memoria entre Argentina y España. Los actores y las actoras sobre las que será puesta la mirada, no son sincronizables en términos generacionales, con lo cual tampoco comparten la misma experiencia ideológica. Y sin embargo en ambos casos se trata de descendientes de una generación que experimentó y respectivamente, en caso de los victimarios, alentó y agendó la historia de las ideologías.

5 Véase https://elpais.com/cultura/2009/12/18/actualidad/1261090811_850215.html (2 julio 2018).

${ }^{6}$ No podemos incurrir en el complejo cuadro de la definición jurídica de la desaparición forzada que, por supuesto, se sitúa en un marco de jurisprudencia internacional (cf. Elsemann; Bolte, Gegen(-) Abwesenheiten).

${ }^{7}$ Véase http://memoriahistorica.org.es/tag/garcia-lorca/ (2 julio 2018). 


\section{Transmisiones y spotlights en la arena pública: arrojando luz sobre los soportes mediales de la 'memoria histórica'}

Desde Argentina, Hugo Vezzetti pregunta: “¿Cuánto dura una determinada formación de la memoria colectiva? Algunas sin duda permanecen por mucho tiempo [...]; sólo una cosa puede decirse: su duración depende de la persistencia de las condiciones que en esa memoria quedan simbolizadas [...]" (Vezzetti 191ss.). De todas formas, la actualización de la visión (o las visiones) del pasado no puede realizarse sin el proceso de la transmisión, donde ésta — más allá de representar un proceso de continuación- incluye interferencias, rupturas y cortes, tanto internos (intersubjetivos e inter-comunitarios) como externos (gubernamentales, extra-nacionales), además puede sufrir transmutaciones abruptas, forzadas. Por otro lado, Vezzetti advierte que en las formaciones narrativas y simbólicas del pasado suelen entretejerse destellos míticos, es decir momentos de estilización y simplificación. Más aún: sin estos momentos de estilización, no sería posible su entrada al espacio público, siendo "la dimensión pública de la memoria" el lugar del cual se extrajeran "las lecciones del pasado" (192) y a través de la cual se tomaran medidas para evitar que se repita una época determinada por la violación de la soberanía cívica. La proyección sobre esta arena puede además conllevar luchas por la memoria (justa, correcta), que hagan uso de diferentes recursos — materiales e inmateriales-:

1. narrativos y literarios en el sentido más amplio (incl. textos y dispositivos documentales),

2. performativos (gestuales, escénicos, 'callejeros'/manifestivos) y

3. biológicos, o más bien bio-políticos (que ideologizan los cuerpos de los ciudadanos y las ciudadanas involucrados en la elaboración del pasado).

Las luchas por la memoria se enlazan con los intereses emergentes del presente, que para organizar su presentificación necesitan de un fundus simbólico, inclusive ficcional. Paul Ricœur ha reflexionado sobre la tensión del trabajo historiográfico que resulta del pulso de reconstruir o hacer presente el pasado y la subjetividad de quien sea motivado por este intento, desdoblándose en 'yo investidagor' ("moi de recherche") y 'yo emocional' ("moi pathétique") (Ricœur 23-43; Dosse). Hay algo, en el trabajo de una reflexión sobre el pasado, que es afectado por este mismo pasado, comparable con lo que ocurre en el trabajo historiográfico. Según Ricœur, se trata de un ejercicio metódicamente disociador: el de asumir la distancia ante lo sucedido en el pasado, además de la tarea de 'traducirlo' según los criterios vigentes para un entendimiento contemporáneo. A la vez, poniendo foco en las reflexiones de Vezzetti, este ejercicio tiende a ser completado en vistas del espacio público y sus estrategias de presentación y difusión, o spotlights que iluminen el pasado ( $i a$ modo benjaminiano?).

El pasado de la guerra de España y subsiguiente dictadura de Franco, no es remoto, al contrario, es reciente, en algunos casos inclusive, inmediato aún. Sin embargo, el trabajo de investigarlo - de sondear en las heridas sociales y políticas y las escasas huellas de los desaparecidos españoles (Torres) — demanda en muchos casos una labor que se adecúe, con objetividad, a los datos que puedan brindar, por ejemplo, la arqueología y antropología forense. El estudio de este pasado requiere, a la par, de una imaginación histórica. Ello se entrecruza con la necesidad y el deseo de trabajo medial, en 
tanto que ciertas aplicaciones y estrategias de los medios están expresamente concebidas para crear y transmitir imágenes, pero también para (re-)configurarlas, es decir 'imaginar' en el sentido más literal.

Una pregunta crucial en este contexto es ¿cuáles podrían ser las posibilidades de la fotografía de des-velar, a su manera medial, narrativas inéditas de la 'memoria histórica' y sus implicancias, tanto objetivas como subjetivas? Otra pregunta, ¿puede la fotografía dar registro de la anatomía ideológica responsable de la división de España, del diagnóstico de las 'Dos Españas' que recibió su fórmula proverbial de la pluma de Antonio Machado y sigue vigente hoy día? Recordemos en esta ocasión que la guerra de España fue una de las primeras guerras mediáticas; y que en Argentina la lucha contra el olvido, a su vez, se inició apoyándose en soportes fotográficos. Además, por entre los modos, los medios y los materiales que componen la matriz de las múltiples estrategias para sustentar las 'memorias históricas', la fotografía conjuga aspectos narrativos - y por lo tanto mnemónicos- y aspectos de 'instantaneización', es decir de puntual presentificación.

\section{Facebook:}

\section{Medios transmisionales de la 'memoria histórica' en Argentina, de la des- cendencia de las víctimas a la descendencia de los victimarios}

En el contexto de la memoria en Argentina los modos, los medios y los materiales que sustenten un trabajo mnemónico crítico, se han ido aplicando de forma crecientemente innovadora debido a ciertas posturas que Naomi Klein asociara con una 'explosiva' generación filial aparecida en el escenario después de la crisis que azotó al país sudamericano en 2001/02 (Klein). Efectivamente, alrededor de esta fecha comienzan a articularse actores y actoras de una nueva memoria: hijos e hijas de desaparecidos que se veían enfrentados con el desafío de elaborar la propia historia familiar afectada por el terror de Estado, y que por otro estaban decididos a poner en práctica una intervención social, política y simbólica contra la crisis nacional del presente (y la posible existencia de nuevos desaparecidos, esta vez sociales: Svampa; Bruzzone ${ }^{9}$. También, empezaron a analizar de forma crítica el 'testamento político' de sus padres (Amado 145, 151; Bolte, Gegen(-)Abwesenheiten 275). Resumiendo, el trabajo de la memoria articulado en Argentina por este grupo conforma un cluster dinámico, basado en un intercambio

\footnotetext{
${ }^{8}$ Ya en la Primera Guerra Mundial jugará la fotografía un rol cardinal; así como también en la Guerra de Secesión de los E.E.U.U., que coincide con el nacimiento de la fotografía. No obstante, en la Guerra de España, la 'fotografía bélica' se inicia como medio paradigmático (y como dispositivo), anunciando el tipo de configuración que la caracterizará hasta nuestros días. La Guerra de España fue objeto de un interés medial inédito; fue marcada por la presencia de cámaras portables (como las armas), que captaron los combates en imágenes fotográficas, y transmitieron un código visual de la guerra. A la vez, la fotografía se convirtió en objeto de manipulación, censura y otros abusos. Las tomas de Robert Capa, Chim, y Gerta Taro, por ejemplo, fueron difundidas en el mundo entero, y además cayeron en manos de la propaganda nazi. Para ver más cf. Paul; Claas. Lamentablemente, no podemos, en el marco de este artículo, ahondar más en la historia ni en la teoría de la fotografía.

${ }^{9}$ Más allá del estudio de la socióloga Svampa en el que se debate el fenómeno de la nueva 'desaparición', la novela de 'memoria travesti' de Félix Bruzzone, Los topos, habla de los "neodesaparecidos" o “postdesaparecidos” (Bruzzone 80).
} 
transgeneracional y a la vez intrageneracional, auto-crítico. Sus métodos fueron y siguen siendo experimentales; algunos transmediales; casi todos meta-mediales - $\mathrm{y}$ siempre meta-mnémicos/mnemónicos- Como lo expresara Albertina Carri en su paradigmática docu-ficción Los rubios, se trataba de "exponer a la memoria en su propio mecanismo" (Carri 00:11:47), incluyendo el factor omisivo del proceso mnémico (el olvido). Otro aspecto que caracteriza a esta generación argentina es su participación de una cultura del espectáculo social/político por la memoria postictatorial: los "escraches" (manifestaciones denunciatorias frente a los domicilios de ex-represores).

En este cuadro de estrategias se han inscrito algunos aspectos biopolíticos, trazando linajes de una memoria que está al cuidado de unas de las primeras activistas contra el olvido, Abuelas de Plaza de Mayo. Cual "detectives" científicos con acceso simbólico a un banco de datos duros (moleculares) sobre el pasado (Amado 137-153), estas se encargan de promover la identificación genética de los hijos de desaparecidos, apropiados en cautiverio. ${ }^{10}$ Tal saber informático entra en el proceso de transmisión postdictatorial y se inmiscuye en las producciones de los descendientes; quienes, empero, contrarrestan el peso simbólico de los mismos mediante estrategias humorísticas (Sosa), porque la memoria cientificista, o 'memoria molecular' (que también formaría parte del sondeo tras los restos de Lorca en España) parece en el fondo inadecuada ante el verdadero escándalo que constituye la ausencia provocada por violencia de Estado y la consiguiente "catástrofe de la identidad" (Gatti, Detenido).

La inscripción más reciente en el campo de la post-memoria argentina, no obstante, se presenta con la aparición de voces hijos e hijas de victimarios (Catela), entre quienes se encuentra Liliana Furió, directora del documental Tango queerido. La documentalista es hija del ex Jefe de la División de Inteligencia (G2) de la VIII Brigada de Infanteria de Mendoza Paulino Furió, quién al ser condenado a prisión perpetua e inhabilitación absoluta y perpetua, cobraría notoriedad con la afirmación: "No estoy arrepentido; volvería a hacerlo" (Furió en Calivares). O Erika Lederer, abogada inclinada a la filosofía y al psicoanálisis — dos campos del saber especialmente reprimidos por el régimen de 1976 - quien declara que su padre fue "el obstetra de la maternidad clandestina de Campo de Mayo ${ }^{11}$ y no lo perdono". Ricardo Lederer optó por el suicidio en 2012, antes de ser condenado; en tanto que Erika Lederer ha iniciado una convocatoria por facebook dirigida a hijos e hijas de represores ${ }^{12}$, bajo la consigna de "aportar datos" y "contar historias" que les sean útiles a la comunidad de los dañados, "porque no hay noción de los daños que aún se siguen produciendo" (Lederer en Lipis).

A casi dos décadas de la aparición en público de las descendientes de las víctimas, los pronunciamientos de estas hijas de los victimarios (hasta el momento son ante todo mujeres; excepto tres hombres, por ejemplo, el abogado Pablo Verna) representan un nuevo eslabón en el proceso de la memoria argentina. Su papel intenta no ser ambiguo

10 Tras el hallazgo del registro de nacimientos de Hospital Militar de Campo de Mayo de los años 1974 a 1978 estas detectives dieron con una explosiva biografía colectiva.

${ }^{11}$ Sobre Campo de Mayo véase nota anterior. El padre de Erika Lederer estuvo además involucrado en los Vuelos de la Muerte (véase Lipis), práctica de exterminio en la que los detenidos-desaparecidos eran arrojados al mar desde un avión. Nota bene: fue Baltasar Garzón ante quien se hicieron las primeras declaraciones en lo relativo a esta práctica (cf. el caso de Adolfo Scilingo, ex Capitán de Corbeta).

12 Véase: https://de-de.facebook.com/historiasdesobedientes (2 julio 2018). 
pero es inevitablemente doble: las nuevas descendientes se rebelan, actual y retrospectivamente, contra el mandato paterno con una postura ostensivamente antipatriarcal, dirigida explícitamente contra los lados machistas y misóginos que dominaron las práxis de la represión (Lederer en El Comercial). A la vez, esta sublevación filial es conflictiva en tanto que existe un innegable vínculo emocional de las acusadoras hacia sus padres. Pese a la carga emocional que implica su coming out, la nueva posición se quiere inamovible, como declara Lederer (2017): "Pienso en voz alta: Los hijos de genocidas que no avalamos jamás sus delitos, esos que gritamos en sus caras la palabra asesino y Memoria, Verdad y Justicia, por pocos que seamos, podríamos juntarnos, para aportar datos que hagan a la construcción de la memoria colectiva."

Simultáneamente, no hay pretensión ninguna de ponerse "en pie de igualdad con los hijos de desaparecidos"; y Lederer agrega: "En todo caso estamos al servicio, pero no nos sentimos con voz." (Lederer en Lipis) De una consciente ambivalencia afectiva parecería surgir ambigüedad a la hora de auto afirmar el deber del testimonio y poner en duda el derecho a la voz.

Entre estas nuevas narraciones de 'la memoria filial' argentina se pueden observar fórmulas afectivas y de iniciación que suelen caracterizar a la formación de un grupo de afectados. Pues la página Facebook iniciada por Erika Lederer, representa un tal grupo de afectados,${ }^{13}$ que con toda razón exhorta a "rellenar" los vacíos que aún contiene 'la memoria argentina', para lograr "historias habitables". Este nuevo discurso se encuentra con ciertos conceptos expresados por los hijos y las hijas de desaparecidos, condensados en las reflexiones de Gabriel Gatti, quien como "hijo", opta por 'sentirse en casa' entre "las cosas inconformes" que rodean a los "post-huerfanitos paródicos" (Detenido 136, 156).

Otro aspecto específico que constituyera el relato de las hijas de los represores, se halla en el hecho de que estas pasan revista de una infancia en la que, en algún momento, descubrían que el propio padre, en nombre del Estado, estaba metido en algo que no tenía nombre. Esta faceta conforma la contracara de lo que descubrían (o no), los descendientes de los desaparecidos, algunos de los cuales, antes de ser secuestrados y asesinados, habían pasado a la clandestinidad. ${ }^{14}$ No obstante, contar la memoria filial siendo hija de un represor parecería ser un ejercicio 'menor' en comparación con la significancia simbólica de la historia de las víctimas, salidas a la luz mucho antes. Las nuevas testigos, empero, denuncian la historia de un sistema que fue construido por sus padres, sobre cuyas criminales mayúsculas comenzó a estructurarse la socialización temprana de ellas como niñas (víctimas a su vez). Asumiendo la probabilidad de equívocos en confrontación con los discursos consensuados de las víctimas directas, las mujeres en cuestión han nombrado su página de Facebook "Historias Desobedientes y con Faltas de Ortografía". También cuentan con una reacción de violencia familiar (micro-representativa del ex-régimen) y un quantum de fragmentarización (que las fa-

${ }^{13}$ Mariana Eva Perez, con su bitácora web Diario de una princesa montonera. $-110 \%$ verdad-, trasladó la escritura sobre la desaparición forzada al mundo de los nuevos medios, y a la vez rompió con todo estereotipo testimonial (Bolte, "Estrategias").

${ }^{14}$ Laura Alcoba por ejemplo en Manèges (2007) cuenta la historia de una infancia en la clandestinidad y sus aspectos lingüísticos: la necesidad de tener que entender los códigos mediante los cuales los adultos se comunicaban para no ser delatados. 
milias de los desaparecidos tuvieron que pagar de forma mucho más atroz), al expulsarse de un linaje social que aportó un dispositivo paradójico a la compleja memoria colectiva: el silenciamiento.

El silenciamiento lleva a la esfera de lo no-verbal, que es de especial interés respecto a los procedimientos de articulación medial de las memorias. En todas las documentaciones sobre actores y actoras sobresalientes de la construcción de la memoria histórica en Argentina, aparece la fotografía como soporte medial. Fueron las Madres de Plaza de Mayo quienes establecieron la 'memoria fotográfica'. Los retratos que estas 'Antígonas' argentinas utilizaron desde el primer día para hacer visible la ausencia de sus hijos e hijas, fueron el elemento inicial en la cadena transferencial de la memoria visual. Más adelante, los hijos y las hijas (los y las nietas de las Madres) continuarían con el deseo de encontrar formatos de (re)presentación de la ausencia de los desaparecidos, sus padres. Según Julio Pantoja, estos actores culturales de la postdictadura argentina poseen un especial "vínculo con la imagen" (Pantoja). Y Diana Taylor acota: "The Grandmothers, the Mothers, the disappeared, and the children establish a chain in and through presentation and representation." (Taylor, Archive 175)

El trabajo de fotografía filial más estudiado es sin duda "Arqueología de la ausencia” de Lucila Quieto [1999-2001] (2011). Esta obra nació tras una convocatoria en el entorno de la agrupación H.I.J.O.S., siendo resultado de un método experimental, heterocrónico y además corporal: Quieto trasladó los cuerpos de los hijos, cual 'tatuajes', a fotografías de los padres desaparecidos y logró que de ahí nacieran collages, entre documentales y utópicos, digitales y análogos (Longoni; Bolte Gegen(-)Abwesenheiten 396-407). Además, existen obras de una generación intermedia, representada por Helen Zout, por ejemplo, o Gustavo Germano.

Las preguntas que guían los estudios de estas producciones son: ¿Qué posibilidades tiene la fotografía de des-velar, en un curso paralelo o coadyuvante, las nuevas narrativas de la memoria histórica, el escándalo de la ausencia? ¿Hablando, pero sin palabras, de la ausentación en sí y la ausentación violenta? Dichos estudios han encontrado importantes respuestas analíticas a estas preguntas. ¿Cuáles son, empero, las diferencias entre estas producciones — muchas de ellas docu-narrativas y centradas en la (des-)figuración de distintas 'categorías' de víctimas- y las representaciones fotográficas que se publican en distintos medios y formatos, de los victimarios argentinos? Veamos aquí la fotografía de Erika Lederer y su padre, publicada en The Guardian. ${ }^{15}$ ¿Cómo leer esta imagen al lado de imágenes como las que realizó Lucila Quieto, por más que los dos medios no tengan relación sincrónica, ya que una es contemporánea a la dictadura argentina $-\mathrm{y}$ nunca hubiera podido ser objeto del 'secuestro' medial ${ }^{16}$ —, la otra post-dictatorial?

15 Véase: https://www.theguardian.com/world/2017/jun/13/argentina-daughters-military-dictatorship-father\#img-3 y http://www.me.gov.ar/a30delgolpe/fotogaleria/lucila_quieto/. (2 julio 2018)

16 Volveremos sobre esto más adelante. 


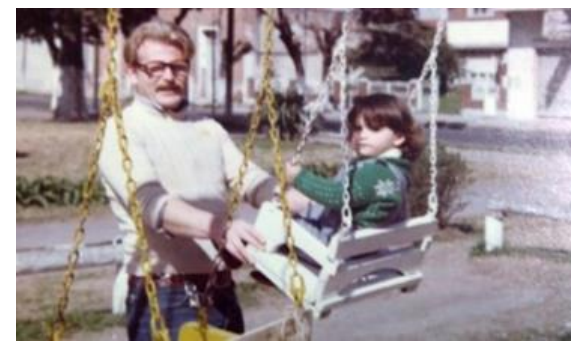

Imagen 1: Erika Lederer y su padre

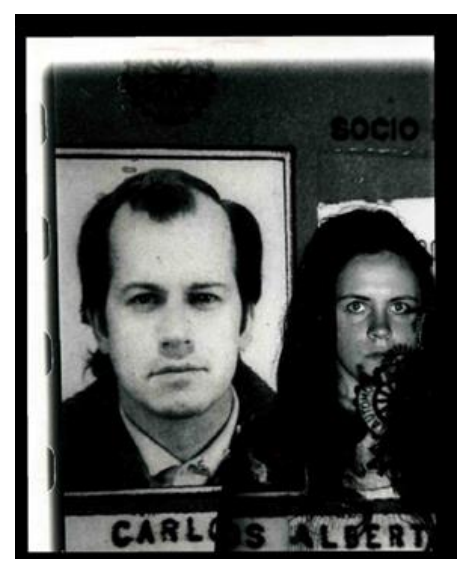

Imagen 2: Lucila Quieto ante una fotografía de su padre

La imagen $\mathrm{n}^{\circ} 1$ es una instantánea intimista que reporta la relación de un padre y una hija, que estuvo impregnada de violencia (microsocial y metonímica). Esta información entra en la lectura de la fotografía ya que en The Guardian va acompañada por algunos de los datos mencionados. La imagen pierde toda inocencia; recibe un surplus inscripcional negativo en términos sociales, políticos y morales. ¿Se colará, sin embargo, un momento de piedad por el padre muerto? Una incógnita hermenéutica. Quizás se entremezclen en la 'lectura' de la fotografía — más allá de las informaciones pragmáticas de la imagen (las signaturas de le época: cromaticidad, vestimenta, etc.) — huellas de la anatomía ideológica de la Argentina de los años setenta. Imposible de fundamentar esta interpretación con una prueba icónica: resta aceptar el conocimiento previo (Vorwissen), adquirido por la lectura de The Guardian, y que esta produzca cierto enturbiamiento icónico (Bildrauschen).

Tras este preview de varios capítulos de la 'memoria fotográfica' argentina, en lo que sigue se realizará una introducción a la problemática de la memoria histórica en España; para que más adelante puedan ser verificados los puntos de contacto y/o comparación entre la obra fotográfica de manos de Gustavo Germano y la de José Aymá; sus aspectos narrativos y de presentificación. 


\section{Transferencias y discursos de la(s) memoria(s) en España: las nuevas cohortes y la 'memoria prótesis'}

Como es sabido, en España, las reclamaciones por una memoria histórica — crítica y analítica- respecto a los acontecimientos que llevaron a la guerra española y a la dictadura franquista desembocan en la fundación de la Asociación para la Recuperación de la Memoria Histórica (ARMH) y la subsiguiente Ley de Memoria Histórica. Ambas instituciones son un ejemplo sin par de una 'lucha' por la memoria. El nacimiento de la ARMH, empujado por la iniciativa personal de Emilio Silva, crítico de la ambigua conducta de la sociedad española frente a la historia de los terrorismos de Estado, fue un verdadero hito. Lo que parecería interesante, es que el periodista y sociólogo haya impregnado su iniciativa con una tajante nota autobiográfica: "Soy nieto de un desaparecido" (Silva, "Mi abuelo"). Efectivamente este enunciado se presta como correlato intercultural de la declaración "Soy hija de desaparecidos, qué hago con eso" (Panizza), suscripta por los y las descendientes de las víctimas del terror de Estado en Argentina, de quienes hablamos más arriba, y entre las cuales se inscriben, grosso modo, estrategias de separación y/o unión, antes las cuales cabe preguntarse si podrían tener utilidad para una traducción al caso español, aunque se trate de distintas generaciones: de hijos por un lado, de nietos por otro.

Respecto a los distintos grados de elaboración de la 'memoria histórica' entre España y Argentina, vale también la pena una mirada a la mencionada 'memoria molecular', pues en España se presentan desafíos con los cuales en Argentina existe ya cierta experiencia. Tras haber salido a la luz la espeluznante verdad sobre los "niños robados" en el país ibérico (Duva y Junquera), se ha entablado una perspectiva transcultural sobre el fenómeno de la apropiación de niños (Álvarez Taboada). Así, desde la bioética, por ejemplo desde la Universitat de Barcelona, se han realizado investigaciones sobre el ADN como instrumento de búsqueda de familiares (Marfany).

No obstante estas iniciativas, Laura Soler Azorín es de la opinión que entre Argentina y España existen "políticas de Estado opuestas respecto a la recuperación de la identidad" en este campo, es decir un décalage entre una "política activa" argentina, y la de España (471). A pesar de los distintos contextos sociales e históricos de esta praxis de apropiación de niños (que de todas formas equivaldría a una adaptación de métodos nazis (Soler Azorín 468)) en España y en Argentina, las vías de difusión frente a un público masivo que necesitaba ser informado para poder colaborar en la búsqueda de quienes fueron secuestrados cuando niños, son comparables. En Argentina se trató de los hijos y las hijas de los desaparecidos, en España de los y las ciudadano/as que nacieron bajo el Franquismo. En ambos países se eligieron estrategias mediales similares como, entre otros, el formato de la serie televisiva (la producción Niños robados en España, Televisión por la Identidad en Argentina) ${ }^{17}$ para hablar de estos crímenes de Estado, en los que colaboraron instituciones como hospitales y la Iglesia.

17 Véase por ejemplo la primera parte de la serie española: http://www.telecinco.es/tvmovies/ninosrobados/parte-1/Ninos-robados-Parte_2_1685280148.html; y la serie argentina en la página de Abuelas de Plaza de Mayo: https://www.abuelas.org.ar/video-galeria/television-x-la-identidad-tatiana13 (2 julio 2018). Soler Azorín equipara estas dos series. 
Más marcada en España, sin embargo, es la dimensión generacional de la 'memoria histórica', dada la circunstancia que el Franquismo abarcó un período de tiempo extremadamente largo. De ahí que una compilación de Julio Aróstegui Sánchez y Sergio Gálvez Biesca, intentando formular un "balance de los movimientos por la memoria", hable de "tres generaciones" mnémonicas (o memorialísticas) de España, como reza el título de la obra (cf. también Aróstegui). Este planteamiento quizás encuentre su eco en Walter Bernecker quien, desde Alemania, rehúsa hablar de una memoria histórica española en singular, prefiriendo el plural: memorias (Bernecker 88). En uno de los ensayos de la mencionada compilación a cargo de Aróstegui Sánchez y Gálvez Biesca, Pedro Ruiz Torres habla de una nueva "cohorte" de la memoria española: "los nietos de la guerra". En este contexto, en el que se remite a Santos Juliá, Ruiz Torres, empero, se muestra además escéptico acerca de "una 'realidad', un 'sujeto', una 'cosa' que pudiéramos llamar 'memoria colectiva' o 'memoria generacional”' (Ruiz Torres 68).

Esta posición es sintomática ya que toda una línea de posicionamientos, críticos y analíticos, dan registro del movimiento por la memoria en España, y entre ellos un considerable número de estudios han intentado trazar y analizar la respectiva "polémica 'recuperación de la memoria histórica"' (Yusta Rodrigo; además Juliá, Ruiz y Espinosa; Pichler, a la par de los estudios ya citados), desglosando las etapas de la confusión existente respecto al 'relato oficial' de la guerra y de lo que vino después. Algunos se han cuestionado acerca de sus 'historias menores'; y parte de ellos nos advierte que la 'memoria histórica' se encuentra en continuo peligro.

Valga retornar a Ruiz Torres: este autor hace una serie de anotaciones pertinentes respecto a las paradojas de las sociedades que se consagraron al 'credo' de una memoria en auge, y sostiene así el rehusamiento terminológico (y conceptual) de la misma, mencionado más arriba. Ruiz Torres parte del hecho de que a la memoria histórica le sería atribuida el desiderátum de una "continuidad ininterrumpida", y que esta contrastaría con el dinamismo de la memoria emitida por los nuevos medios. Estando sin embargo tan involucrados en las nuevas memorias, estos proporcionarían una disminución de la memoria individual. El resultado: una "memoria prótesis" de ademán presentificador y una carencia de interés historiográfico (72 ss.).

Ante estas advertencias, parecería que el movimiento por la memoria en España hubiera no solamente incitado a la derecha a una abierta estrategia de denigración del prolongado terror causado por la guerra de España y la dictadura franquista, sino también suscitado una perspicaz atención desde los que la estudian, quienes se apresuran a tocar la alarma suponiendo que el proyecto podría resultar contaminado por una hermenéutica de amateur (Aróstegui y Gálvez Biesca 11).

Tal oficiosidad científica es indudablemente necesaria; por otro lado también puede ser considerada un bienvenido filón para la argumentación desde aquel bando, obstaculizador, de la sociedad española que vivió "perfectamente instalada dentro de las estructuras de la dictadura franquista" y que por lo tanto temió (y teme) "el despertar de la bestia" memorialística y el hecho de que se airéen los testimonios de las víctimas (Aróstegui 92).

En términos generales, los estudios de la memoria emiten los resultados de sus propios acercamientos, sistemáticos, pero también analizan expresiones de y sobre la memoria, formulados desde distintos niveles de erudición (y posición ideológica). Dan registro de cómo estos distintos niveles de enunciación entran en circulación. Uno de los campos de mayor competencia frente a este proceso dinámico e intercomunicativo, 
es el de la terminología. Esto puede apreciarse cuando expertos, desde afuera, intentan encontrar términos para la descripción del caso español. Por ejemplo, Christian von Tschilschke hace uso de la imagen 'cambio de mareas' (Gezeitenwechsel, en alemán), al datar la partida paradigmática en campos de la cultura de la memoria en España a más de veinte años de la muerte de Franco. Es evidente que el autor utiliza este término para poder introducir su objeto de estudio con mayor precisión, el 'cambio mediático' (Medienwechse) de la novela Soldados de Salamina de Javier Cercas (2001) al cine, por David Trueba (2003) ${ }^{18}$ Con el primer vocablo (Gezeitenwechsel), Tschilschke trae a colación un término acuñado por el historiador Norbert Frei, estudioso consagrado a la memoria histórica alemana (von Tschilschke 269). El término alemán es semánticamente más rico, ya que contiene el lexema '-zeiten' (tiempos) —y quizás por ello ilustre adecuadamente el valor del intercambio transcultural de los estudios de la memoria—: estos asimismo implican momentos de traducción, trasvasamiento, así como también asumen y trabajan con el surplus que nace de lo intraducible. ${ }^{19}$

En el preámbulo de su estudio, von Tschilschke se refiere además a la creciente desaparición biológica de los testigos directos de la guerra española, para a la vez remarcar la aparición —o irrupción- cultural de una generación sucesora que carece de una relación mnémica directa con la historia de la dictadura franquista. Es decir que von Tschilschke coincide en su observación con Pedro Ruiz Torres y otros autores españoles. Además, von Tschilschke llama la atención sobre una 'cohorte' con poderes de interpretación e importante inserción discursiva, que en relación a la elaboración del pasado histórico en España califica como un deber moral, pero que simultáneamente no se abstiene de aprovechar los aspectos y usufructos comerciales que el ingreso de la memoria a la esfera en términos del divertimento conlleva. Este autor alemán señala también que tal actitud generacional sería más permisiva frente a los recursos mnemónicos y los modos de la conmemoración en el nuevo siglo — con lo cual correspondería con aquel grupo que Erice Sebares identifica como "no hipotecado por los recuerdos personales" (105)—. Se trataría entonces de la generación que abre el camino hacia un campo de crítica más distanciado frente a las secuelas afectivas del pasado histórico, iniciado con la guerra de España. Von Tschilschke a la vez observa, que en la elaboración de la memoria histórica española, las estrategias de Bewältigung (término psicoanalítico para el acto de procesar o elaborar) se entrecruzan con otras, de Bewahrung (conservación) del pasado. Esto, siguiendo a Tschilschke, ocurre justamente en el pase intergeneracional; pase que en Alemania, en cambio, al menos en términos oficiales, no habría ocurrido (von Tschilschke 270).

\footnotetext{
${ }^{18}$ Entre los estudios alemanes, véanse al respecto además: Wildner; Jünke 74-99.

${ }^{19} \mathrm{El}$ intercambio acerca de las memorias históricas en España y Alemania fue objeto de un simposio llevado a cabo en el Instituto Cervantes de Berlín, en mayo de 2005. Véase la respectiva publicación (Keilholz-Rühle y Olmos). Con respecto a las memorias -así como también los procesos de transición e identidad- entre Europa (España y Alemania) y América Latina (Argentina), véase además la reciente publicación de Piovani, Ruvituso y Werz. Esta compilación de estudios reúne miradas teóricas y metodológicas provenientes desde las Ciencias Sociales sobre los puntos de contacto así como también sobre las diferencias en la elaboración del pasado dictatorial y los procesos de democratización en los países mencionados.
} 


\section{“Conoce a los nietos de Franco"/“Quién sabe si los hijos de JRV viven?" Perfiles de descendientes españoles y argentinos en la prensa y los foros}

Las persistencias ideológicas que legitiman la continuada vigencia del narrative de las 'Dos Españas' (Manganas), se ponen de manifiesto en continuaciones monumentales, por ejemplo el Valle de los Caídos (Elsemann 146s.) ${ }^{20}$ por otro lado se muestran de forma más sutil, y a la vez mediática. Sobre el horizonte de los medios masivos en España, pueden hallarse reportajes dirigidos hacia una audiencia masiva, que parecerían entablar de una forma bastante natural los vínculos familiares con el legado de la época dictatorial, al informar sobre la vida de los nietos y las nietas de Francisco Franco.

Tal es el caso de un reportaje en El Mundo de noviembre 2015, donde se lee acerca de los descendientes de Francisco Franco: "Carmen es la más mediática; Mariola corrió delante de los grises; Arancha salió mucho tiempo con su primo; Merry es la más hippie del clan; Francis es el 'heredero' de su abuelo; Jaime, el más alocado y Cristóbal dejó el ejército y se casó con una conocida presentadora. Conoce a los nietos de Franco." ${ }^{21} \mathrm{La}$ invitación a "conocer" a los nietos de Francisco Franco, identificando entre ellos a su heredero simbólico y tuteando a la audiencia, da fe de la (frívola) desenvoltura con la cual parecería reafirmarse, bajo el spotlight del mundo mediático y como si de una revelación en 'la dimensión pública del olvido' se tratase (para invertir las palabras de Vezzetti), la legitimidad de la estirpe de un ex "Jefe de Estado", "y punto" (Constenla). ${ }^{22}$

Para retomar la comparación del estado de las memorias históricas en España y Argentina, cabe observar que, en el país del Cono Sur, durante la dictadura se realizaban reportajes de la índole del citado con el fin de dar a las familias de los militares una imagen honorable. Como señala Celeste Vazquez en un artículo sobre el papel estratégico que jugó la prensa durante la dictadura de 1976, diarios y revistas funcionaron prácticamente como "voceros de las Fuerzas Armadas en el poder", promulgando la ideología y también el lenguaje de estos. Concertando una verdadera "campaña de propaganda", de la cual participaron prominentemente las revistas Somos, Gente y Para Ti, que mezclaban "farándula con política", al general Jorge Videla se lo introdujo a la sociedad ya antes del golpe de 1976 (Vázquez; además Schindel 84, passim). Durante la dictadura, entretanto, la prensa sería el soporte de un sistema del "given-to-be-invisible" y el "given-to-be-seen" (Taylor, Disappearing 119): es decir que reproducía, a nivel medial, la praxis de exiliación de los perseguidos por el régimen que, además de ser

${ }^{20}$ Para más detalles sobre el debate más reciente, a saber, el pedido por una reconstitución del Valle de los Caídos acorde a las recomendaciones del Comité contra la Tortura y al Grupo de Trabajo sobre las Desapariciones Forzadas de la ONU; y las observaciones de Pablo de Greiff al respecto, véase http://www.diariodejerez.es/espana/ONU-Espana-franquismo-Guerra-Civil_0_1137486967.html (2 julio 2018).

${ }^{21}$ Véase http://www.elmundo.es/album/loc/2015/11/13/56463bfd268e3e7f0d8b4605_4.html. (2 de julio 2018)

22 Valga recordar un episodio crítico ocurrido en 2011, cuando se debatió el hecho de que en el Diccionario Biográfico Español el historiador Luis Suárez denegaba el título de 'dictador' para hablar de Francisco Franco (Kunz 224; Elsemann 175 et al.). Véase también Constenla. 
víctimas físicas de crímenes de lesa humanidad, fueron objetos de un "disembodiment" (4) y un "percepticidio". ${ }^{23}$ Por otro lado, los medios se hicieron cargo de la hipervisibilización de los dictadores. Si Pantoja subraya el fuerte lazo que mantienen los hijos y las hijas de los desaparecidos en Argentina con los medios visuales, se debe entre otras cosas a esta experiencia histórica socio-medial en cuyo contexto fueron desaparecidos sus propios padres (actos de allanamiento en los que a menudo también resultaban 'secuestradas' las fotografías familiares, como mencionamos brevemente más arriba).

Resumiendo: la prensa argentina rezaba la ideología patria y colaboraba en la construcción de una imagen ideológica y visual inmaculada, de los responsables del terrorismo de Estado. Como anotara Vazquez, en Gente se publicó una nota que incluía una presentación de los integrantes del gobierno instaurado en marzo de 1976, "con una foto y un pequeño Curriculum Vitae de cada uno" — formato que recuerda al reportaje aparecido en ElMundo-.



Imagen 3: Jorge Videla en familia, retratado por la revista Para ti (1979) (Vázquez)

\footnotetext{
${ }^{23}$ El término "percepticidio" remite a Juan Carlos Kusnetzoff (Bolte, Gegen(-)Abwesenbeiten 32, 8392).
} 


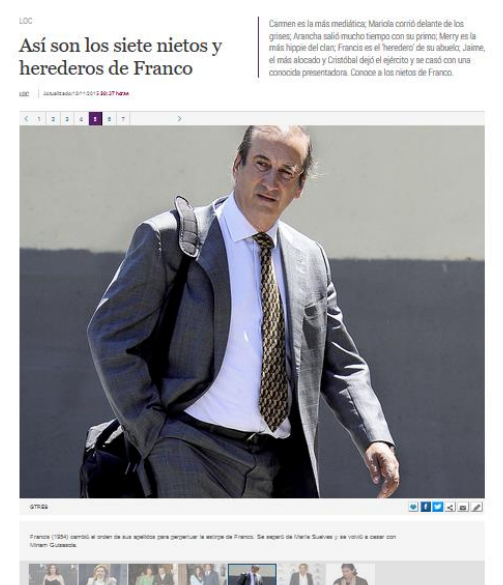

Imagen 4: El nieto de Francisco Franco retratado por ElMundo (2015)

Tras la redemocratización, sin embargo, una presentación halagüeña de los ex participantes del terrorismo de Estado en Argentina, es difícilmente imaginable; o al menos no se encuentra tan fácilmente como en el caso español. Aunque El Mundo no retrate victimarios, sino a los descendientes de un dictador, el tono parecería sintomático en referencia a la sospecha de que las 'Dos Españas' pudiesen seguir existiendo.

En Argentina, la prensa con ocasión de la muerte de Jorge Videla (ocurrida en 2013) más bien observó la vida de los y las descendientes del ex dictador de una forma perspicaz, como demuestra un artículo en Perfil, donde dice: "Es hija de Videla y tiene un simbólico Falcón verde" (Straccia). El comentario se refiere a la hija de Jorge Videla, María Cristina Videla, que estaría reivindicando a su padre fallecido "con un homenaje que hiela la sangre": haciendo uso de un Ford Falcon, vehículo vuelto símbolo de los secuestros cometidos bajo el régimen. El artículo identifica y nombra el número de matrícula del coche y brinda otras informaciones más. Va acompañado por una serie de fotos que dan fe del ademán investigativo de la prensa, que su vez va mezclado con una retórica sarcástica (“Ahora se compró un 0 km, pero no se desprende del Ford.”). Las fotos (imágenes 5 y 6$)^{24}$ muestran, en calidad de toma de paparazzo, al objeto en discusión, el automóvil, y a su dueña.

24 Véase: http://www.perfil.com/elobservador/es-hija-de-videla-y-tiene-un-simbolico-falconverde-0906-0146.phtml (2 julio 2018) 


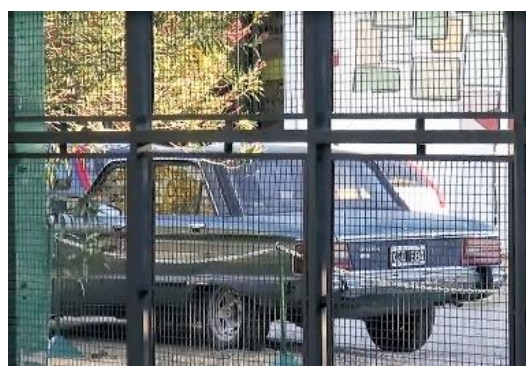

Imagen 5: Ford Falcon de María Cristina Videla

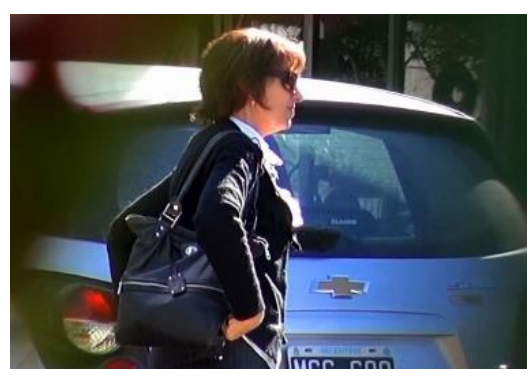

Imagen 6: María Cristina Videla

El artículo es ácido; y señala que San Luís, lugar de residencia de la descendiente de Videla, sería una ciudad "Videla-friendly". De repente, se hace entrever un décalage de las políticas de la memoria histórica a nivel intranacional, entre la cuales Buenos Aires ocuparía probablemente el papel más progresista. Se presenta una categoría analítica que podría ser transferida a los estudios de la memoria histórica en España (en forma de una cartografía de la 'memoria nacional').

Otro lugar de información consagrado a la inquietud acerca de la herencia genética y simbólica de Jorge Videla se encuentra por ejemplo en un foro de preguntas y respuestas (en Yahoo). ${ }^{25}$ Aquí, se manifiestan posturas interrogativas y al mismo tiempo opiniones "Videla-friendly":

\section{¿Quien sabe si los hijos de JRV viven o estan en otro pais?}

Tenia siete hijos,,no se si era viudo o no???alguien sabe????

\footnotetext{
${ }^{25}$ Véase: https://ar.answers.yahoo.com/question/index?qid=20130520112748AA8UxSO (2 julio 2018).
} 


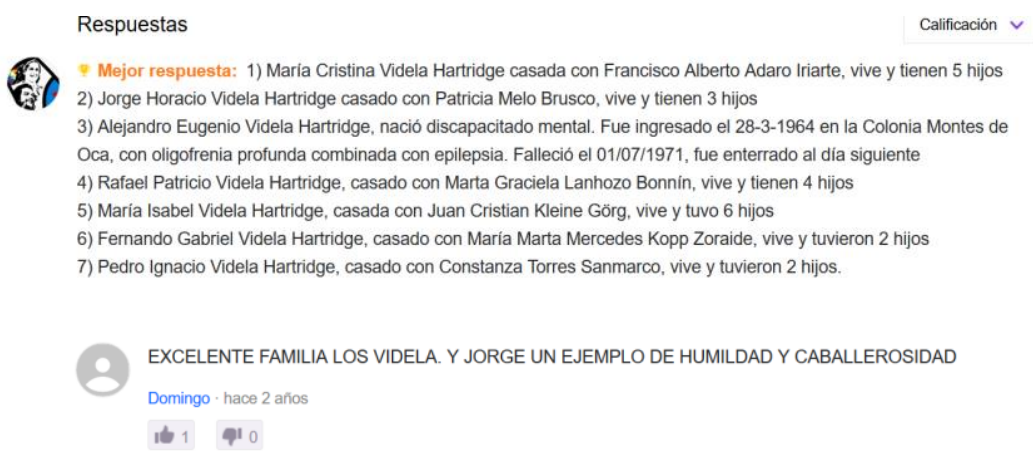

Los foros representan una parte de las comunidades comunicacionales con reglas propias, en las que no podemos ahondar, aunque sí podemos advertir que en ellos la 'memoria histórica' es reasociada a los mecanismos de una praxis mnemónica colectiva, social y comunitiva, — de características (para-)orales- que adquiere una dimensión oximórica nutrida justamente de un déficit de consenso oficial. ${ }^{26} \mathrm{~A}$ la vez, tanto respecto al artículo publicado en Perfil como respecto a las entradas en el foro citado, se debería verificar si la cultura de los escraches encuentran un cierto eco.

Por último, cabe recordar la ya comentada fotografía de Erika Lederer y su padre (imagen $n^{\circ} 1$ ), también publicada en la esfera de la prensa y puesta en circulación en el marco de un debate crítico a primera vista consensuado en Argentina. Independientemente de que los reportajes sobre las descendientes de los victimarios en Argentina distan formal y éticamente de la representación que se hace en España de la estirpe de los Franco, tal como se entrelee en el reportaje de El Mundo, el aporte de Lederer inaugura algo eminentemente incomparable: aquí se trata de descendientes que han decidido hablar enfrentándose críticamente con el pasado.

Ante este panorama y a modo de resumen, valga apuntar que entre los recursos mnemónicos que las sociedades postdictatoriales tienen a disposición, se inscriben las estrategias orales y a la vez, existen los paradigmas de una memoria "condensada" (Assmann 117ss.), apareciendo entre ellos los suplementos (hiper-)tecnológicos de la memoria orgánica (cerebral, corporal, ritual). Entendemos que estos suplementos de la memoria orgánica, además de las formas mnemónicas y mnémicas más abiertas y dinámicas, como las estrategias aplicadas por la generaciones de la postmemoria, tomando el término de Marianne Hirsch, y los debates en la prensa y otros medios masivos, inclusive los que implican los comentarios prosumer, las formas narrativas (inclusive literarias) y las performativas (gestuales, 'callejeras'), así como sus implicaciones bio-políticas (desglosadas más arriba), construyen el complejo de una cultura de la memoria (en plural) que reúne cualidades de almacenamiento y opciones para la 'descarga', la apertura e inclusive la 'iluminación’ (Assmann, ibid.). Por lo tanto debemos asumir que en la dialéctica o tensión medial de todos estos formatos, así como también en los recorridos mnemónicos/mnémicos extra-mediales, se inscriben los conflictivos aspectos que conlleva la cuestión del pasado histórico: la pregunta acerca de a quién le pertenece el pasado.

Esta negociación toca la cuestión de las pertenencias a nivel político y social, simbólico y medial y, también, comercial. Por ejemplo, una obra como Soldados de Salamina,

\footnotetext{
${ }^{26}$ Véase nuevamente nota 1.
} 
escrita por un autor que critica y la vez saca provecho de la cultura de la memoria en España, se acerca a una figura del bando de los vencedores y victimarios de la guerra de España (el escritor falangista Sánchez Mazas). Por el otro lado, una serie televisiva ilustrativa como Niños robados demuestra la envergadura de los medios de masas para con un objetivo social y político, a través de "una nueva perspectiva que se abre camino en la ficción de compromiso con la realidad imperante" (Soler Azorín 470). Ambos acercamientos conforman partes lícitas de un proyecto en construcción de envergadura transgeneracional y transcultural.

Ahora, la pregunta es si en el campo de la fotografía de arte - ejemplificada en este artículo por la obra de José Aymá-, se encuentran otras perspectivas mediales que puedan ser consideradas iluminadoras respecto a este proyecto, y cuáles serían sus aspectos específicos en términos de estética, además de sus enlaces transculturales (con la obra de Gustavo Germano). Antes de aproximar esta cuestión, un preámbulo expondrá el contexto medial de la obra fotográfica de Aymá.

\section{¿“Los hijos de la reconciliación"? Imágenes light de un encuentro entre descendientes de generales enfrentados en la guerra de España}

En junio de 2016, tiene lugar un encuentro entre hijos y nietos de generales que se enfrentaron en las trincheras de la guerra de España; entre ellos el ya mencionado Francis Franco. Además participan José Andrés Rojo, hijo del general republicano Vicente Rojo; José Luis, nieto de José Moscardó, que encabezó la sublevación del frente nacional en Toledo; María Eugenia Yagüe, hija del general Juan Yagüe, para nombrar los más prominentes. Este encuentro será documentado por el fotógrafo José Aymá ${ }^{27}$ quien tomará determinadas medidas estéticas para realizar los retratos, y será transcrito en un artículo periodístico (Landaluce y Ortiz) publicado en El Mundo, con el título: "Los hijos de la reconciliación". La reunión será también registrada por un vídeo de Javier Nadales, llamado "Un encuentro histórico". ${ }^{28}$

Lo primero que llama la atención es que este film lleva adelante una sinopsis de la confrontación de los dos grupos de descendientes mediante ciertos recursos suavizantes, por ejemplo la cámara lenta; o el uso de una música de fondo notoriamente harmoniosa. A través de estas estrategias estéticas se transmite claramente la idea de una "imagen de la concordia" (Francis Franco en Landaluce y Ortiz) que al parecer habría reinado sobre la reunión que se realizó en ocasión del $80^{\circ}$ aniversario del inicio de la guerra de España. Valga mencionar, en este contexto, que con ocasión de los 80 años del inicio de la guerra de España se realizaron una serie de documentales televisivos, inspirados en algunas series europeas sobre la Segunda Guerra Mundial, y sus modos de presentación de materiales visuales, entre ellos España: Ensayo de una guerra, producida por el canal Historia ${ }^{29}$, o la miniserie documental España dividida: La Guerra Civil en color, emitida por Discovery MAX y realizada en colaboración con la Filmoteca Española. Las imágenes históricas — muchas de ellas inéditas hasta ahora —usadas en

27 Para más información véase: http://efti.es/staff/jose-ayma (2 julio 2018).

28 El vídeo tiene una duración de 6:34 minutos. Véase http://www.elmundo.es/cronica/2016/07/17/57890937468aeb592b8b45ff.html (2 julio 2018).

${ }^{29}$ Véase: http://canalhistoria.es/programas/espana-ensayo-de-una-guerra/ (2 julio 2018) 
estas producciones provienen desde ambos bandos del conflicto, con el fin de que se logre "no una visión, sino una visualización" de lo que fue la guerra de España-. La intención fue entonces la de "lanzar una mirada moderna y plural", carente de "tópicos, maniqueísmos y juicios de valor" (Sanz Esquerro).

El motor de este intento de modernización de la narración del conflicto español consiste en nivelar la "carga narrativa" de la guerra de España de implicancias emocionales (Ángel Bahamonde en Sanz Esquerro). Un añadido es el uso de recursos infográficos e icono-tecnológicos altamente modernos que siguen la estética del vídeojuego o del 3D; otro recurso cardinal es el de los reenactments de batallas realizados en zonas reales de combate. ${ }^{30}$

La obra de Nadales compagina recortes de la conversación llevada a cabo entre los descendientes de quienes participaron de los combates de España; el tenor es el de un intercambio de cortesías, en el cual se entremezclan algunos momentos mnémicos expresados por uno/a que otro participante. Por ejemplo, el testimonio de Francis Franco quien comparte el recuerdo de su abuelo - Francisco Franco- llorando el último día de la guerra. Como si se tratase de un encuentro en privado con el ex dictador; un benévolo recuerdo de uno de los dictadores más longevos de Europa. A la par, queda por completo oculta una dimensión factual; no se nombran cifras (que hablen de los muertos y de los desaparecidos), ni fechas; y mucho menos se evidencia lo que (en términos de muertos y desaparecidos) vendría después de la guerra. De tal modo, se impone la impresión de que el encuentro se hubiese realizado bajo un mandato apaciguador cual intercambio de fórmulas que confirman la buena voluntad post-conflictiva de todos los involucrados. A diferencia de los y las descendientes de las víctimas y los victimarios del tiempo de terror en Argentina, no se hace mención de aspectos ideológicos, y mucho menos se analizan. Tampoco se hace uso de términos como 'justicia' o 'elaboración'; ni de conceptos como, justamente, 'memoria histórica'. Un leitmotiv, empero, es la confirmación, archiconocida en el contexto de la 'memoria española', de no 'abrir las trincheras' nuevamente.

¿Cómo se posiciona el vídeo, en tanto que soporte registrador, ante este escenario? Destaca, más allá de los efectos suavizantes ya mencionados, un truco fílmico en el retrato de la reunión que podríamos llamar tableau vivant, porque efectivamente parecería tratarse de pacíficas estatuas vivientes que reiteran, en una versión light y sonriente, las posturas de antaño. Llama además la atención el uso del plano picado en algunas secuencias. Esta técnica de angulación es la opuesta al plano contrapicado, usado con frecuencia a su vez en la propaganda fascista. La cámara registra en varias tomas los pies de lo/as participantes; esto ocurre ante todo al principio, en tomas a cámara rápida (como si estas quisieran retratar el paso del tiempo del pasado histórico hacia el presente del encuentro). En la mitad de la película, en cambio, se extrapolan los pies de Francis Franco, que se mueven mecánicamente, nerviosos (2:27-2:29).

Ahora, para ensamblar las distintas categorías de imágenes, es decir las que están en movimiento, como las televisivas y las de vídeo — las de Nadales, por ejemplo-, con las imágenes estáticas de la fotografía, como elementos de un intento de visualizar

30 Véase: http://es.dplay.com/dmax/espana-dividida-la-guerra-civil-en-color/ (2 julio 2018). Véase además, y retomando las observaciones respecto a los intercambios transculturales en el campo de los estudios de la memoria, también la serie alemana, en el canal público ZDF: Die Wahrheit über Franco: Spaniens vergessene Diktatur: https://presseportal.zdf.de/pm/die-wahrheit-ueber-franco-spaniensvergessene-diktatur/ (2 julio 2018). 
las narraciones de la guerra de España: ¿qué decisiones toma Aymá para sus retratos fotográficos? Y, ¿ hay efectos 'colaterales' que podrían ser interesantes, más allá de un análisis semiótico de la imagen?

A la sesión fotográfica de Aymá en el sentido estricto, le precede un acto 'coreográfico’ interesante, según la descripción del reportaje en El Mundo: el fotógrafo desea que lo/as participantes se unan, y después decide dividirlos en dos equipos que reproduzcan los bandos ideológicos de los padres o abuelos. Pero los retratados se niegan; el nieto del dictador pronuncia: " $¿[\ldots]$ nos vamos a colocar unos en un lado y otros en otro? A mí no me parece bien." (Francis Franco en Landaluce y Ortiz) De tal manera se desarma la formación pensada por el fotógrafo. El artículo periodístico describe como toma cuerpo este 'desarme', por ejemplo cuando María Eugenia Yagüe, hija del general responsable de la matanza de Badajoz (agosto de 1936), explica: "Y yo me cambio a este lado", mientras que el hijo de un protagonista republicano asiente; y el texto de prensa transcribe: "[...] se oye a uno de los representantes del ala republicana dirigiendo sus pasos a la zona nacional." (ElMundo) Como si se tratase de un reenactment, pero reformulado bajo los signos de una post-memoria post-ideológica. Ante este trasfondo, nacen fotografías que a continuación serán puestas en correlación y en contraste con el método de trabajo del fotógrafo argentino Gustavo Germano.

\section{Las uniones/separaciones fotosensibles de José Aymá y los dípticos fo- tográficos de Gustavo Germano}

La producción de Germano más conocida es "Ausencias" de 2006. ${ }^{31}$ Esta reúne catorce fotografías familiares históricas tomadas en Argentina en los años setenta y otras catorce tomas correspondientes, realizadas varias décadas después, siempre en el mismo lugar donde fuera realizada la toma original, y reproduciendo el setting de esta. Germano opta por un formato específico, el díptico. Las duplas de "Ausencias", unidas tras una (invisible) bisagra meta- o heterocrónica, dan testimonio ex negativo de la desaparición forzada de al menos una de las personas presentes en la toma original, como en este caso que muestra al fotógrafo mismo y a sus hermanos: ${ }^{32}$

${ }^{31}$ La publicación en forma de libro data de 2007. Germano además ha realizado variantes de este proyecto, que tienen como objeto la desaparición forzada en Brasil, Uruguay y Colombia (2012-2106). Cf. la página web del fotógrafo www.gustavogermano.com (2 julio 2018).

32 Véase: http://www.gustavogermano.com/ Imagen 11 de 15. Se trata de una fotografía en la cual aparece Gustavo Germano con sus hermanos. Eduardo Germano fue desaparecido en diciembre de 1976. Al respecto: http://www.desaparecidos.org/arg/victimas/g/germano/ (2 julio 2018). 


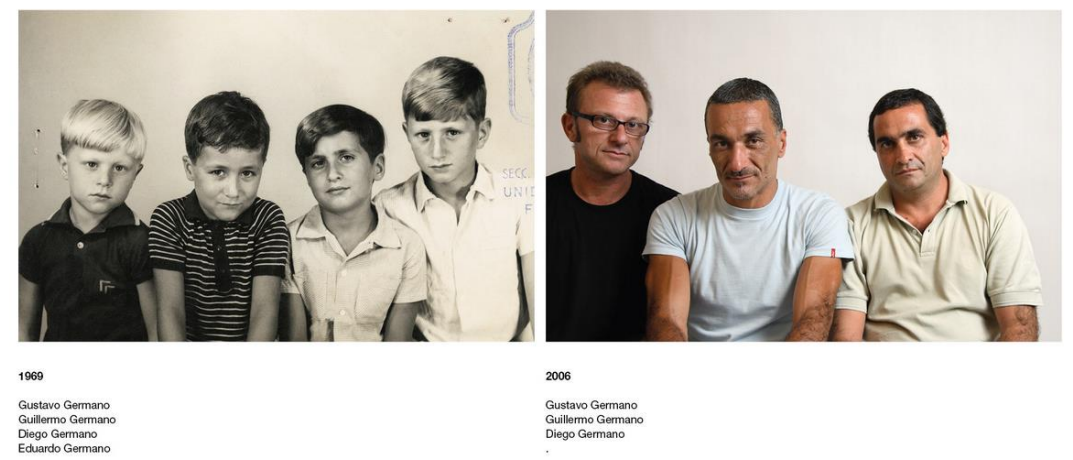

Imagen 7: Gustavo Germano: "Ausencias"

El díptico se remonta a una tradición eclesiástica, en la que éste representaba un soporte para la inscripción de los nombres de personas beneméritas o mártires; o también de los difuntos que se recordaban durante el acto litúrgico. Tales dípticos coexistían con los dípticos de vivos, y esta tradición, en uso hasta el medioevo tardío en Occidente, desembocó en distintos formatos de sistematización cronológica: entre ellos los calendarios y las necrologías, es decir dispositivos de registro de actividades y sucesos, las efemérides. Obviamente, en el momento de analizar la serie de dípticos seculares de Germano, viene también a la mente esta tradición del tríptico piadoso, de formato portátil y de función devocional y oracional. Pero Germano introduce, además, recursos estilísticos recursivos, anafóricos como elementos narrativos. En una toma de los años setenta por ejemplo se ve la misma mesa que en la fotografía tomada décadas después, ${ }^{33}$ señalando que el objeto perduró todo ese tiempo, a diferencia de tres de las personas retratadas ya que estas fueron desaparecidas. La imaginaria bisagra entre las dos tomas representa, en el fondo, un gap - elemento estructural del arte secuencialque condensa lo inenarrable.

Para resumir el gesto deíctico de "Ausencias" valga diferenciar que las tomas que datan de la década de los setenta visualizan un número de constelaciones y escenas familiares, cumpliendo justamente con las convenciones de género del retrato familiar, mientras que sus contracaras postdictatoriales narran las historias de la supervivencia, mostrando quién sobrevivió la dictadura argentina del 1976 y quién no. La presencia de quienes sobrevivieron resalta a la luz de la ausencia de quienes ya no son más visibilizables, por haber sido asesinados y sus restos mortales haber sido desplazados. ${ }^{34} \mathrm{O}$ como dijera Gabriel Gatti:

33 Véase imagen 3 de 15: http:/ /www.gustavogermano.com/ (2 julio 2018).

${ }^{34}$ Germano aplica otra técnica más, apostrófica y la vez criptográfica: el uso del asterisco (cf. Bolte, “Estrategias"). En las fotografías en la cuales las víctimas de la desaparición causada por la última dictadura argentina están visiblemente ausentes, el respectivo nombre de la persona forzosamente de-presentada, pero, en contraste, aún presente y nombrada en la fotografía original, es substituida por este glifo. 
Todas las fotos contienen una falta, y esa ausencia es tremendamente contundente. Hay algo ahí que no se ve pero que llena. Y que oprime y sobrecoge: mirar una foto es soportable, y dos y tres...Pero la serie completa produce un efecto terriblemente turbador, el de descubrir que el vacío, perdón, que ese vacío, está lleno (Gatti, Detenido 120).

Los retratos de José Aymá, en su organización formal hacen pensar en la obra de Germano; pero ante todo en otro trabajo de este fotógrafo argentino, a su vez serial: "Distancias" (2006-2009). ${ }^{35}$ En esta obra, Germano sigue desarrollando el "punto de partida" de "Ausencias", trabajando sobre "los conceptos de temporalidad" y la puesta en paralelo de las imágenes $\left(\right.$ Berger $\left.^{36}\right)$. En "Distancias" las fotografías se expresan sobre el exilio republicano español, sobre el "destierro" de aquellos de los cuales muchos nunca volverán.

$\mathrm{Al}$ igual que en "Ausencias", Germano elige el 'des-tiempo' para esta obra: la destemporalización, como concepto, y el arreglo heterocrónico como técnica. Hace uso de material de archivo - fotos de testigos directos cuando eran niños- para compaginarlos con tomas actuales de estos testigos que, a causa de su avanzada edad pronto no podrán más contar su historia. De tal forma, hace patente y visible el paso del tiempo y la(s) historia(s) que se han inscrito en él, como engramas que trazan el recorrido de incontables desplazamientos violentos, de los cuales algunos se vuelven ejemplares gracias al lúcido dispositivo de la fotografía. A ambos lados de la bisagra se encuentran dos retratos separados por siete décadas: una imagen reflejada en la otra a través de un re-escenificación de lo que muestra la fotografía de partida. ${ }^{37}$


\footnotetext{
35 Véase http://www.gustavogermano.com/gallery/distencias/ (2 julio 2018).

${ }^{36} \mathrm{El}$ comentario se encuentra en el blog de Germano y data de 2013: gustavogermano.com/blog/ (2 julio 2018).

${ }^{37}$ Imagen 4 y 15 de 15. Véase http://www.gustavogermano.com/\#distancias (2 julio 2018).
} 


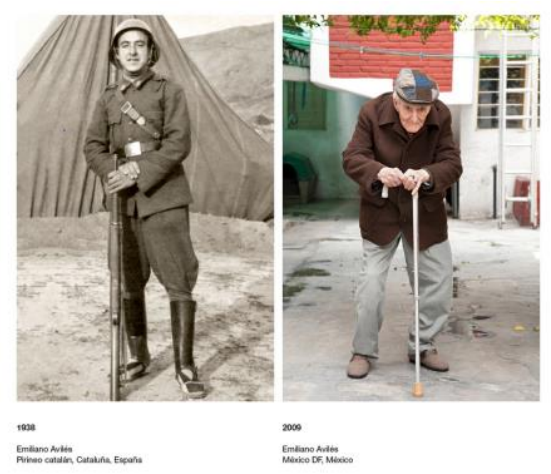

Imágenes 8 y 9: Gustavo Germano: "Distancias"

La transmisión del pasado congelado en este medio, la toma de los años 1930, que no es tanto un pre-medio, ya que dialoga de una forma equilibrada con la toma actual, sucede a través de un salto en el tiempo. De ahí que podríamos hablar de una serie metaléptica, que reúne imágenes profanas u oficiales (p. ej. fotografías de documentos de identidad) y las transciende hacia un plano de significancia mnemónica en el contexto de la(s) 'memoria(s) histórica(s)' del mundo hispánico (además de Francia, mucho/as de los exiliados retratados se encuentran en México). En este marco, las imágenes dan fe de la permanencia de los traumas causados: las "heridas invisibles" (Berger) del trauma cobran relieve en el formato del díptico que abarca elementos del reenactment: en el presente se vislumbran trazos del pasado.

¿Qué tienen que ver estas fotografías de Germano con aquellas de Aymá, que retratan a los descendientes de generales republicanos y nacionales en las trincheras de la guerra, guerra que conllevó un flujo de refugiados, algunos de los cuales serían retratados por Germano en imágenes separadas y al mismo tiempo unidas, del pre- y post-desplazamiento?

Dice John Berger: "Una fotografía es un punto, un instante detenido en el tiempo. Dos fotografías son dos puntos, dos instantes detenidos en el tiempo que determinan la línea que los une, reconstruyen la historia, revelan y denuncian la violencia imprescriptible del exilio. Dos puntos, dos lugares, dos momentos unidos en un gesto de memoria." Más allá del paréntesis historiográfico —el registro del evento histórico de la guerra española - en el caso de la obra de Germano se trata de una observación de la diferencia; de las diferencias efectuadas por el paso del tiempo, como factor objetivo por un lado, y por otro de las diferencias (traumáticas) causadas por la sustracción de la identidad cultural y nacional tras el exilio.

Aymá también sondea la categoría de la diferencia a través de la yuxtaposición en formato de díptico; sin embargo sus fotografías son sincrónicas. Muestran respectivamente a dos sujetos sobrevivientes, descendientes de un tiempo ideológico que causó muchos miles de muertos y desaparecidos; crímenes que tuvieron sus responsables. La primera toma de la serie es quizás la más impactante porque en ella parecería que las 
diferencias entre el nieto del dictador Franco y Enrique Líster, hijo del general republicano Enrique Líster, tendrían una correspondencia con ciertos clichés fisiognómicos: ${ }^{38}$

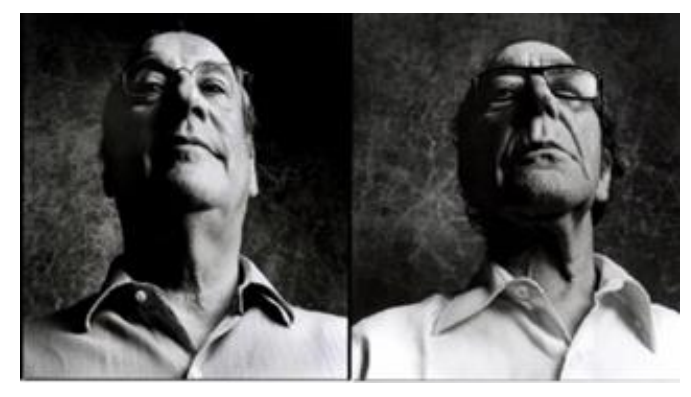

Imágenes 10 y 11: Francis Franco y

Enrique Líster, por José Aymá

Esta impresión se debe, sin embargo, a ciertos recursos fotográficos empleados. Desde ya, ambos retratados visten una camisa clara, sin corbata, cuyo botón superior está abierto. Ambos retratados llevan anteojos. Sin embargo la faz de Francis Franco se muestra notablemente más lisa; el chiaroscuro que domina las fotos modela la expresión de suficiencia de Franco; y la de suspicacia en la cara de Líster. En cierto modo, en este último caso, también podría hablarse de una cara más marcada. El cristal izquierdo de los anteojos de Líster parece ahumado, o reflejar algo —un efecto óptico metafórico (que conlleva un cierto Bildrauschen)—. El ángulo elegido por el fotógrafo corresponde a un contrapicado, que logra un escorzo que distorsiona los rasgos al punto tal de aproximarlos. Por ejemplo, la curvatura de las bocas es casi idéntica a pesar de que la de Franco insinúa abiertamente una sonrisa, mientras la de Líster todo lo contrario. El fondo — ¿una superficie arañada, un mármol de textura inquieta? — no está iluminado de la misma forma; el fondo del retrato de Francis Franco es más oscuro; la cara del retratado en consecuencia resulta más iluminada, su piel más clara.

En vez de recurrir, fotográficamente, a la categoría del enfrentamiento (histórico) de los dos sujetos fotografiados, Aymá opta por la yuxtaposición de los dos retratados, volviéndolos dupla a pesar del relato factual del binarismo ideológico que enfrentó a sus antecesores. Un verdadero enfrentamiento en el dispositivo fotográfico se hubiera podido realizar, por ejemplo, mediante una toma de perfiles en formato face to face. Sin embargo, esto no se habría correspondido con la idea de la reconciliación. Aunque quizás sí con la idea de un encuentro 'en igualdad de condiciones', un cara a cara.

La estrategia de Aymá pese a dar la impresión de superación de un viejo conflicto ya pasado, parecería haber sido entonces la de equiparar la imagen del nieto de Francisco Franco y la del hijo de Líster, fundador de la PCOE, sobre una línea, en un 'horizonte facial' que sugiere un estatus de unión. De la misma manera, Aymá retrata a María Eugenia Yagüe y a José Luis Escobar (nieto de Antonio Escobar, quién rindió

38 Véase: http://www.elmundo.es/cronica/2016/07/17/57890937468aeb592b8b45ff.html (2 julio 2018). 
sus tropas ante Yagüe). Este estatus podría sustentar el intento de re-acentuar el relato de la reconciliación entre las 'Dos Españas' en ocasión del $80^{\circ}$ aniversario de la guerra.

En la unión que sugiere la dupla fotográfica en cuestión, empero, se intercala el ademán de una división que parecería trazar las huellas de una histórica anatomía ideológica, así como también las sombras presénticas de un campo de batalla, del cual resultaron vencedores o vencidos. En todo caso, la lectura de esta dupla de imágenes estará siempre influenciada por el Vorwissen de que en el caso de Líster, se trata del hijo de un general republicano, y en el de Franco del nieto de un vencedor. Lo cual lleva a leer en la imagen $n^{\circ} 11$ la marca facial del vencido; y una expresión complementaria en la imagen $n^{\circ} 10$.

¿Es comparable este arreglo fotográfico elegido por Aymá con las variadas estrategias aplicadas en la obra de Gustavo Germano, que expusimos?

Sin duda, el efecto logrado en las obras de Germano se vuelve problemático en la producción de Aymá, porque en Germano no se trata de 'imaginar' la historia de una rivalidad en un salto transgeneracional, sino de captar el paso del tiempo de un trayecto biográfico determinado por la experiencia de la violencia histórica y de trazar las continuidades identificatorias que, no obstante la tragedia histórica vivida, siguen siendo visibles en un sujeto, o son logradas por ciertos arreglos de decorado, etc.

Otras preguntas: ¿Son comparables las constelaciones (Aufstellungen, en el sentido psicoanalítico) mnémico-generacionales que ocurren bajo la dirección de Aymá con las que ocurrirían en Argentina, de forma explícita en la obra post- y biodramática Mi vida después de Lola Arias, donde la dramaturga argentina reúne a hijos e hijas de víctimas y victimarios? (Arias; cf. Bolte, Gegen(-)Abwesenheiten 495-519) ¿Los y las retratadas por Aymá, se preguntan qué hacer con su estatus filial, descendiente? ¿Retumba en su encuentro la fórmula de Emilio Silva "soy nieto de un desaparecido"? ¿Existe entre ellos una noción de 'catástrofe' y/o un ademán paródico, como el que Gabriel Gatti reclama para su camada? ¿ ¿ sería más conveniente aplicar la noción de lo anastrófico? ¿Existe expresión alguna acerca de los ideales por los cuales lucharon los padres o abuelos? ¿O se trata ante todo de apostar por la reconciliación? ¿Credo que sustentaría, a posteriori, el narrative de la guerra de España como un mito (para-universal)? (Jünke 48-61; 98)

Esta cascada de preguntas tiene, por supuesto, la siguiente función: demostrar, por un lado, y reiteradamente, que los casos no son comparables y que por lo tanto la transferencia de varias de las preguntas no es lícita. Desde ya, porque los retratados no tienen el estatus de actores culturales o artísticos, como lo tienen muchos de los descendientes de víctimas y victimarios en Argentina. De modo que correspondería preguntar, además: ¿Cuál es la filiación de Aymá?

Por otro lado, las preguntas hechas más arriba dan fe de que el intento de un traslado de cuestionamientos prima facie, intransferibles, representa el gesto de curiosidad necesaria para que un sondeo tenga lugar.

$\mathrm{El}$ sondeo de la(s) 'memoria(s) histórica(s)' no es posible sin el soporte y las estrategias de los medios, estos 'almacenadores y generadores de información' (Jünke 63), que tal como observa von Tschilschke, se debaten entre la colaboración y la competencia -al igual que los/as actore/as que los suministran-. Vezzetti subraya que el espacio público en el cual se pugna por la memoria (y su la visión más lícita, o más urgente, etc.) "se alimenta de la contradicción, incluso de la división" (Vezzetti 193). De tal modo, este se convierte en un campo que dice mucho sobre el presente, sobre 
los intereses y la proveniencia de sus actores (gubernamentales, institucionales, singulares, pero organizados en agrupamientos cívicos de derechos humanos o de académicos; y otros, no reconocidos oficial- o socialmente, apartados, marginados).

Los aspectos elucubrados en este ensayo son parte de una inquietud sobre el espacio medial y actoral de la memoria histórica social, incluidos los mecanismos aparentemente paradójicos: los mecanismos de separación que necesita la construcción del complejo y dinámico entramado que representa la memoria en colectivo, además de la entrada de esta en las memorias transculturales.

Nina Elsemann, en su valioso estudio, ha recorrido los caminos de un intercambio ejemplar tocante a los saberes del hacer memoria entre Argentina y España, que experimentan luchas locales de la memoria, y a la vez se se sitúan en marco de las dinámicas del transfer entre distintas comunidades. Estas comunidades pueden ser descritas con la categoría de lo nacional ('la memoria española' y 'la memoria argentina'), como es el caso en este ensayo; no obstante, y más aún teniendo en cuenta los nuevos acontecimientos en Argentina, cabría relativizar la idea de una política de la memoria impulsada por un gobierno (que suele ser limitado en el tiempo, limitándose con ello también el alcance de sus iniciativas, intervenciones o inversiones respecto a la elaboración del pasado histórico).

A la vez, urge enfocar las posibilidades de los medios: las opciones de la fotografía, por ejemplo, para visibilizar lo invisibilizado. Con todas sus implicancias de instantaneidad por un lado, y de registro fantasmagórico por otro lado; enfocando su papel registrador de 'obra de cámara' como lo es el retratado encuentro entre lo/as descendientes de los generales españoles; su papel público, su difusión, su entrada a los medios masivos.

Igualmente cabe anotar que por más que se hable de la desaparición de la corporalidad en los medios, estos son capaces de registrar y transmitir o transmutar a los aspectos bio-políticos; la presencia de unos u otros cuerpos, o su ausencia.

Las obras fotográficas que analizamos en este ensayo ponen a la vista el cuerpo de varias 'series' de sujetos, involucrados de distintas formas en la experiencia de un pasado (en plural), que hoy es el objeto de memorias históricas fuertemente debatidas o divididas. Las obras de Aymá y Germano muestran las distintas caras de un tiempo oscuro que solamente puede ser iluminado en sus divisiones, recurriendo a las estrategias mediales más diversas. Lo sorprendente es que en las dos obras se registra un ademán narrativo —ante todo en Germano, ya que el gesto de Amyá sin dejar de 'contar' algo, resulta más preséntico- pese a que los medios visuales, como anotara Jünke (66), no poseen un tiempo (gramatical) para el pasado.

\section{Cierre: ¿"Industria del guerracivilismo" desde Argentina? O del on- y el offline de la 'memoria histórica'}

Para cerrar, se presenta una idea de otro campo de intercambio transcultural de memorias entre Argentina y España: el literario. Cabe mencionar el caso de una joven escritora argentina que se inscribe en la narrativa sobre la guerra de España, que obligó a sus abuelos a exiliarse en Sudamérica. Con ello, participa de la mnemografía literaria dedicada a la historia del terror y la violencia acaecidos en el mundo hispánico. Andrea 
Stefanoni (nacida en 1976, cuando se instala el régimen de Videla) lanza en 2015 una novela titulada La abuela civil española. En este texto, la autora hace memoria sobre la trayectoria de sus parientes.

Bajo sospecha de ser partícipe literaria de una "industria del guerracivilismo" etiqueta aparecida en España tras el debate iniciado por Javier Cercas ${ }^{39}$-, Stefanoni insiste en que los acontecimientos del pasado vivido por sus abuelos actúan aún en el presente.

Este aserto se sobreentiende si partimos de ciertos axiomas anticipados no solamente por Walter Benjamin sino, finalmente, más que aprobados por los estudios de la memoria. Sin embargo, el ejemplo de esta novela argentina pone de manifiesto una postura filial, descendiente, que nos interesa. Aunque basada en parte en el gesto entre patético y banal de afirmar que la propia escritura y por lo tanto autoría (sobre la historia narrada) no hubiera sido posible si los abuelos no hubiesen huído de la guerra, la obra de Stefanoni nos parece relevante como ejemplo de cómo la lucha en torno a la memoria histórica en España puede encontrar ecos transfronterizos desde Latinoamérica y de la pluma de la generación más joven (recordando que este intercambio, en el fondo, tiene una larga tradición en la historia de los exilios). ${ }^{40}$ Por otro lado, si partimos de la suposición de una cultura global — coyuntural— de la memoria, así como también de un auge de una literatura explícita de la memoria, debemos reconocer que esta literatura conlleva su respectivo 'mercado'. Este mercado encuentra su representación y resonancia (más instantánea, horizontal o descarada, en fin: micromediática) en internet. Y en este contexto, la obra de Stefanoni no es solamente producto de una cultura de la transferencia entre España y Argentina, sino además objeto de la transferencia de la mnemografía y la meto-mnemografía al espacio de los nuevos medios. Es decir: al igual que el foro, mencionado más arriba, consagrado a la descendencia de Jorge Videla, en la página del diario que reseña el libro de Stefanoni aparecen comentarios de usuarios. Estos son agrios y reflejan posiciones entre revanchistas, sabiondas, ominosas y puramente escépticas frente al campo de la producción cultural consagrada a la memoria histórica: ${ }^{41}$



\footnotetext{
${ }^{39}$ Según esta lógica el término/concepto de 'Memoria Histórica' sería el teaser de una estrategia de marketing.

40 Véase al respecto el evento "América Latina y el mundo ante la guerra civil española", llevado a cabo en Bogotá en los días 4-9 de abril de 2011. Https://bifea.revues.org/1700 (2 julio 2018).

41 Https://www.elconfidencial.com/cultura/2015-07-18/guerra-civil-memoria-historica-andreastefanoni_932459/ (2 julio 2018).
} 


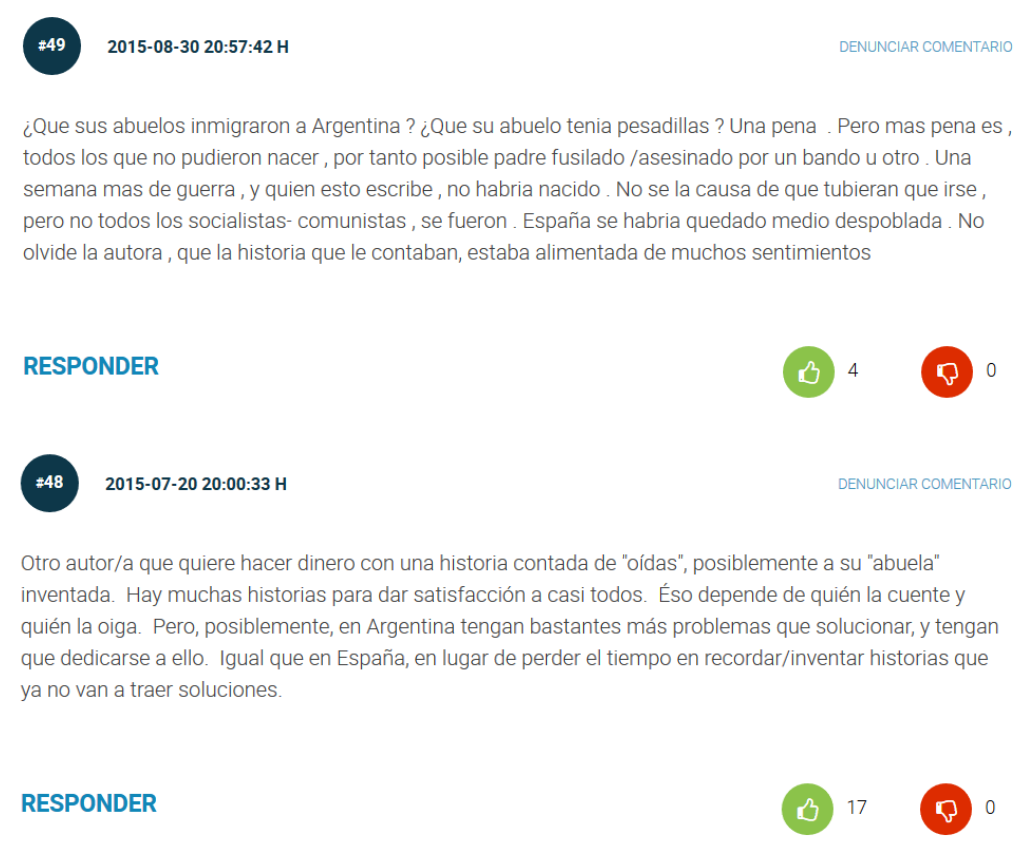

Valdría la pena realizar una exégesis detenida de estos comentarios y muchos otros más, que servirían como ejemplo de ciertas fórmulas típicas entre las comunidades que se expresan en la Web. El marco de este artículo nos impide profundizar el análisis de estos comentarios en los que, como estudiamos en otra ocasión, ya mencionada (Bolte, "Estrategias"), juegan un rol importante las fórmulas mnemónicas que comparten un trabajo de la memoria virtual, aunque estas siempre están conectadas con los discursos offline, es decir: una mixed memory por antonomasia.

Paralelos a estos foros dinámicos, pensados para que el público comente ofertas comerciales dedicadas a la memoria histórica (en este caso la novela de Stefanoni), corren los proyectos de las asociaciones civiles entregadas al trabajo mnemónico empírico (y muchas veces: 'afectado'). En los sitios virtuales de asociaciones o agrupaciones como Proyecto Desaparecidos (Bolte, Gegen(-)Abwesenheiten 135) ${ }^{42}$ o de la ARMH, que en parte brindan acceso al mundo de los archivos (digitalizados), no caben (aunque los hay) comentarios como los citados. Tanto más necesario sería su análisis.

Llama la atención que se comente de forma negativa el hecho que Stefanoni sea argentina; este dato identitario conduce a la sospecha de que la autora habría inventado la historia que narra (para vender su libro). No se menciona el concepto de una memoria transcultural. Tampoco se postean comentarios meta-literarios (aunque sí paródicos (cf. \#49)); además los comentarios no se interconectan realmente entre sí; no se realiza ni una super- ni una intra-visión.

Tanto más destaca un post que parecería remitir a alguien de amplio conocimiento histórico, especialmente de la historia de los vencidos en Europa, aunque este aporte resulte demasiado proliferante y un tanto desubicado. La crítica de este comentarista, que se identifica como "nieto y sobrino de un fusilado por los vencedores de la guerra civil" trabaja en base a la fotografía, como un medio de la verificación.

\footnotetext{
42 Véase nota 35 donde se cita una entrada en este proyecto.
} 
Dicho comentario recibirá más likes (23) que aquellos que mostramos más arriba. Sin embargo, las intervenciones que más likes recibieron son dos (\# 42 y \#43), uno de los cuales es posteado por un familiar ("a mi abuela le mataron dos hijos"). Ambos coinciden en que no se legitimaría "avivar" el horror (que según \#43, nieto de aquella mujer que perdió un hijo por parte del bando fascista, otro por el republicano, habría sido olvidado con buena razón); \#42 queda "emocionado" con el posteo de \#43 y aprovecha la ocasión para disertar sobre la extendida historia de las batallas sobre suelo ibérico, concluyendo que: "[...][en] esta península nos hemos dado estopa durante siglos, por lo que en estos tiempos que estamos viviendo la temporada de paz más larga de nuestra historia lo que conviene es hacer énfasis en lo que nos une y postergar lo que nos divide (no olvidarlo) porque si no por culpa de los rencorosos esto va a ser el cuento de nunca acabar." Este comentario recibe la mayor cantidad de likes. ¿Cómo evaluar el resultado de esta contabilidad?

Los prosumers que accedieron a este sitio en internet encuentran una pseudónima unidad en el post que opina que la acción narrativa frente al horror histórico sería dañina, por interminable; y que esta infinitud (del relato de la división) se cristalizaría en forma de una continuada división. El comentario de este "lector influyente" equivale a una petición en favor de un momento narrativo cero; o de una censura de la actitud narrativa que Ricœur indicó como fundamental para nuestra relación con la historia.

¿Qué dice la autora del libro en cuestión? La autora no aparece en estos foros. Parecería no tener necesidad de intervenir, o el mercado (la editorial) no le otorgó la función de intervenir. Ante la ausencia de un meta-comentario autoral, recurrimos al inicio de la página en cuestión: aquí se encuentra una entrada no-verbal, la reproducción de una toma fotográfica realizada por Robert Capa en 1939, que muestra una corriente de exiliados republicanos en Francia. ${ }^{43}$



Imagen 12: Robert Capa

43 Https://www.elconfidencial.com/cultura/2015-07-18/guerra-civil-memoria-historica-andreastefanoni_932459/ (2 julio 2018). 
Hay, otra vez bajando al sitio dedicado a la novela de Stefanoni, un primer comentario que comenta esta imagen: "Refugiados republicanos españoles camino del campo de concentración de Argelés" (\#50). Aquí nadie cliqueó ningún button; ni likee, ni dislikee. La toma "original" de Capa circula bajo la representación de la agencia de fotografía Magnum Photos y se encuentra en internet con la siguiente información divergente: "FRANCE. Le Barcarès. March, 1939. Exiled Republicans being marched on the beach from one internment camp to another area by a French policeman (Negative from the "Mexican Suitcase"). ${ }^{44}$

Nadie parece haber verificado los datos de \#50; el mismo comentarista tampoco remite a la fuente de su epígrafe. Pero aquí no se trata de controlar la cientificidad de las entradas realizadas por una comunidad de prosumers, sino de trazar el recorrido de estas; el estado emocional infeccioso que comparten algunas de ellas y su falta de intertextualidad con respecto a los meta-textos sobre la memoria histórica, a saber los discursos oficiales o de publicidad offline, por más controvertidos que sean. También es interesante el encabezado fotográfico del artículo sobre la novela de Stefanoni, porque el medio de la fotografía no solamente cumple un papel fundacional en la historia de la guerras modernas, al registrar los acontecimientos durante la guerra de España (como antesala de la II Guerra Mundial) ${ }^{45}$, sino igualmente porque siguiendo a los planteamientos de las ciencias de la imagen este medio/arte, tan sustancialmente temporal — pasado y preséntico a la vez (Knaller 93)—, sería un correlato mnemónico consustancial al modo narrativo, en tanto que según Ricœur (y Didi-Huberman, ${ }^{46}$ entre otros) le brinda a la imaginación una función imaginativa en el sentido literal, complementando la 'legibilidad' del pasado, con la 'visibilidad' (Stoellger 195).

La obra de Gustavo Germano, que se ha destacado como una obra significativa en la labor de reflexionar la historia de la desaparición forzada en Argentina, da indudablemente fe de esto. En España, la fotografía referida a la memoria histórica que fuese experimental, o conceptual al menos, aún está por formarse. Tanto más, los retratos de Aymá, su modo de visualizar aspectos de unión y de separación entre los y las descendientes de los generales de la guerra de España, son relevantes; y una prueba del papel tan eminente que juega la fotografía en el arte de la transmisión de saberes sobre el pasado. La breve 'lectura fotográfica' del encuentro entre descendientes de los dos bandos enfrentados en la guerra de España que brindó este ensayo, es solamente un inicio. Reiterando que de ninguna manera pretendemos comparar los casos de la memoria histórica y colectiva de Argentina y España en términos políticos; ni en términos de las metáforas políticas (como las de las 'Dos Españas' y los 'Dos demonios'), subrayamos el valor de las observaciones semióticas, siempre que se sitúen en el cuadro más general de las reflexiones sobre la transmisión de memorias competitivas y el papel específico que juegan en ella los soportes mediales.

Por lo tanto mencionamos otro capítulo de la muy consecuente obra de Gustavo Germano, que a su vez pone énfasis en los aspectos sinergéticos de la memoria transcultural: el proyecto “Búsquedas”, dedicado al caso de los 'niños robados' en España.

${ }^{44}$ Http://pro.magnumphotos.com/image/NYC106145.html (2 julio 2018).

45 Véase otra vez nota 8 .

${ }^{46}$ Entre las reflexiones de Didi-Huberman, en parte contestatarias a las de Ricœur, se encuentran el concepto de la "survivance" y la 'temporalidad anacrónica' de las imágenes (Didi-Huberman; Stoellger 194s.).

${ }^{47}$ Http:/ /www.gustavogermano.com/\#busquedas (2 julio 2018). 
Como aclara justamente Gabriel Gatti, esta práctica criminal desemboca en un "relato común" que atraviesa "la historia reciente de España, desde el fin de la Guerra Civil, en 1939, hasta bien entrados los años 90 del siglo XX". Germano se hace cargo de traducir facetas de este relato al medio visual — y a la vez lo compagina con la historia de la búsqueda de un instrumentario, llevada a cabo por Abuelas de Plaza de Mayo, su lucha contra el olvido (argentino), mediante los métodos de la identificación molecular-: ${ }^{48}$

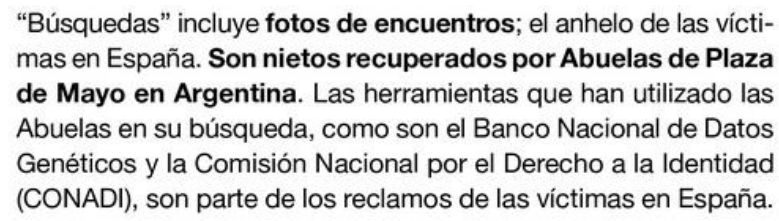

Germano retrata algunos resultados de esta búsqueda, con la intención expresa de que contribuyan como medios de anticipación a quienes en España recién están organizando una tarea de eminente importancia para la sociedad española. En la imagen n ${ }^{\circ} 13$, inundada de un significante blanco, una mujer que busca a su hermana nacida en 1964; en la imagen $\mathrm{n}^{\circ} 14$, dos hermanos argentinos de los cuales uno, que fue dado en adopción ilegal tras el asesinato de su madre (ocurrido junto a otro asesinato que tocó una familia retratada en la serie "Ausencias"), recuperó su identidad genética en $1995 .{ }^{49}$

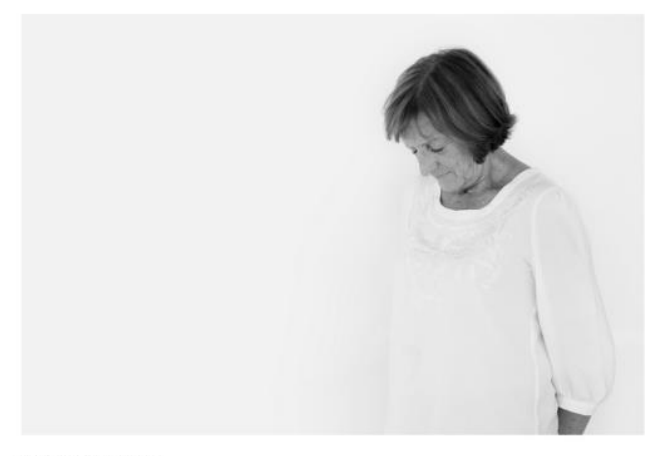

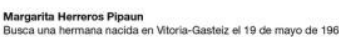

48 Véase http://www.gustavogermano.com/\#busquedas (2 julio 2018).

49 Imagen 10 de 23; imagen 22 de 23. Véase http://www.gustavogermano.com/\#busquedas (2 julio 2018). 


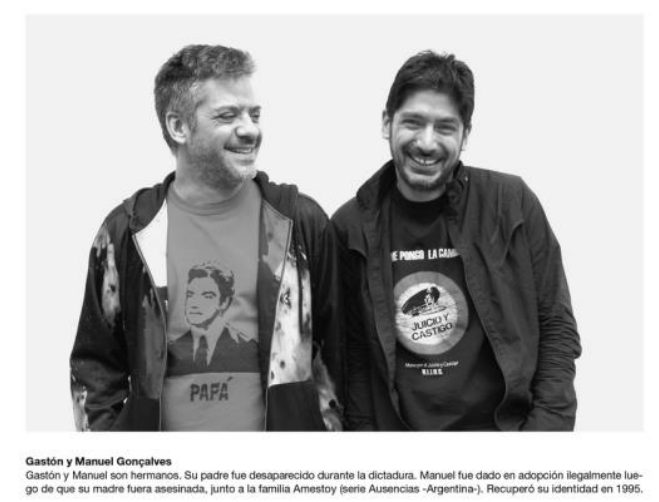

Imágenes 13 y 14: Gustavo Germano, "Búsquedas"

La serie de Gustavo Germano, por lo tanto, representa una cámara lúcida contra la zona gris de una historia, llevada a la luz de la España postdictatorial a muy avanzada hora, y que aún está sin resolver. Las fotografías finales de esta serie estatúan un modelo transatlántico esperanzador y participan de la construcción de un nuevo mito: el de la búsqueda post-dictatorial y sus finales abiertos.

\section{Referencias}

Alcoba, Laura. Manèges. Paris: Gallimard, 2007.

Álvarez Taboada, Lorena. "Las denuncias en los casos de los 'niños robados'. Perspectiva histórico-legal". Desapariciones forzadas de niños en Europa y Latinoamérica. Del convenio de la ONU a las búsquedas a través del ADN. Ed. María Casado y Juan José López Ortega. Barcelona: Universitat de Barcelona, 2015. 279-298.

Amado, Ana. "Herencias. Generaciones y duelo en las políticas de la memoria". Revista Iberoamericana 202.69 (2003): 137-153.

Arias, Lola. Mein Leben danach. Frankfurt am Main: Verlag der Autoren, 2010.

Aróstegui, Julio. España en la memoria de tres generaciones: de la esperanza a la reparación. Madrid: Editorial Complutense, Fundación Largo Caballero, 2007.

Aróstegui, Julio y Sergio Gálvez Biesca (Ed.). Generaciones y memoria de la represión franquista: Un balance de los movimientos por la memoria. Valencia: Universitat de Valencia, 2010.

Assmann, Aleida. Erinnerungsräume. Formen und Wandel des kulturellen Gedächtnisses. München: C.H. Beck Verlag, 1999.

Berger, John. “Ausencias... Distancias”. www.gustavogermano.com (2013). Web. 2 julio 2018. 
Bernecker, Walter L. "El debate sobre las memorias históricas en la vida política española". Escribir después de la ditadura. La producción literaria y cultural en las postdictaduras de Europa e Hispanoamérica. Ed. Janett Reinstädler. Madrid/Frankfurt am Main: Iberoamericana/Vervuert, 2011. 63-96.

Bolte, Rike. Gegen(-)Abwesenheiten. Memoria-Generationen und mediale Verfabrensweisen kontra erzwungenes Verschwinden (Argentinien 1976-1996-2006), Berlin, Humboldt-Universität, 2014. Web. 2 julio 2018.

Bolte, Rike. "Imágenes de la desaparición. Acerca de las series fotográficas de Helen Zout, Julio Pantoja y Lucila Quieto (Argentina 1996-2001)". Narrativas del terror y la desaparición en América Latina. Eds. Liliana R. Feierstein y Lior Zylbermann. Buenos Aires: EDUNTREFF, 2016. 53-71.

Bolte, Rike. "Memoria, material, mimesis. Estrategias contra(re)presentativas frente a la desaparición forzada". DES/MEMORIAS. Eds. Silvia Spitta et al. Barcelona, 2016. 127-155.

Bolte, Rike. "Estrategias y enlaces de Diario de una princesa montonera. $-110 \%$ verdad(2009-2012_****), de Mariana Eva Perez". Donde no habite el olvido. Herencia y transmisión del testimonio en Argentina. Ed. Emilia Perassi y Giuliana Calabrese. Milano: Universidad de Milano, Di/Segni, 2017. 79-97.

Bruzzone, Félix. Los topos. Buenos Aires: Mondadori, 2008.

Calivares, Daniel. “Megajuicio: 'No estoy arrepentido, volvería a hacerlo', dijo uno de los acusados". Uno (6 julio 2017). Web. 2 julio 2018.

Carri, Albertina. Los rubios. Argentina/EEUU, 2003. Film.

Catela, Sonia. “La patria del miedo”. Página 12 (25 noviembre 2017). Web. 2 julio 2018.

Cercas, Javier. Soldados de Salamina. Barcelona: Tusquets Editores, 2001.

Claas, Marco. Der Aufstieg der Falange Española. Faschistische Kultur und Gewalt im Nordwesten Spaniens. Göttingen: Vandenhoeck und Ruprecht, 2016.

Costenla, Tereixa. "Franco no fue dictador, y punto". El País (22 mayo 2012). Web. 2 julio 2018.

Cuesta Bustillo, Josefina. "Memorias, olvidos y amnistías en la democracia española (1975-2007). Su elación con los procesos latinoamericanos". Vielstimmige Vergangenheiten - Geschichtspolitik in Lateinamerika. Ed. Berthold Molden y David Mayer. Wien: Lit-Verlag, 2009. 103-122.

Dosse, François. "Le moment Ricœur". Vingtième Siècle, revue d'histoire 69 (2001): 137152.

Duva, Jesús y Natalia Junquera. Vidas robadas: una investigación periodística rigurosa que arroja luz, sobre el robo de niños en España y el papel de las instituciones. Madrid: Aguilar, 2011.

Elsemann, Nina. Umkämpfte Erinnerungen: Die Bedeutung lateinamerikanischer Erfahrungen für die spanische Geschichtspolitik nach Franco. Berlin: Campus, 2010. 
Erice Sebares, Francisco. "Combates por el pasado y apologías de la memoria". Generaciones y memoria de la represión franquista: Un balance de los movimientos por la memoria. Ed. Julio Aróstegui y Sergio Gálvez Biesca. Valencia: Universitat de Valencia, 2010. 74-108.

Furió, Liliana. Tango Queerido. Argentina, 2016. Film.

Gatti, Gabriel. El Detenido-Desaparecido. Narrativas posibles para una catástrofe de la identidad, Montevideo: Trilce, 2008.

Gatti, Gabriel. Identidades desaparecidas: Peleas por el sentido en los mundos de la desaparición forzada. Buenos Aires: Prometeo Libros, 2011.

Germano, Gustavo. Ausencias. Barcelona: Casa América Catalunya, 2007.

Goñi, Uki. "Sins of the father: daughters of men who killed für Argentina's regime sepak out". The Guardian (13 junio 2017). Web. 2 julio 2018.

Hirsch, Marianne. "The Generation of Postmemory". Poetics Today 29.1 (2008): 103128.

Hirsch, Marianne. The Generation of Postmemory. Writing and Visual Culture after the Holocaust. New York: Columbia University Press, 2012.

Huberman-Didi, Georges. Devant le temps. Histoire de l'art et anachronisme des images, Paris: Minuit, 2000.

Juliá, Santos, Pedro Ruiz y Francisco Espinosa. Sección "Notas y Debates". Generaciones y memoria de la represión franquista: un balance de los movimientos por la memoria. Dossier a cargo de Sergio Gálvez. Hispania Nova 7 (2007). Web. 2 julio 2018.

Juliá, Santos. "Bajo el imperio dela memoria". Revista de Occidente 302/303 (2006): 720.

Junquera, Natalia. "Ningún juez quiere abrir la fosa de García Lorca... ni ninguna otra”. El País (10 septiembre 2012). Web. 2 julio 2018.

Jünke, Claudia. Erinnerung, Mythos, Medialität: der spanische Bürgerkrieg im aktuellen Roman und Spielfilm. Berlin: Erich Schmidt, 2012.

Keilholz-Rühle, Nikky e Ignacio Olmos (Ed.). La memoria histórica en España y Alemania. Frankfurt am Main/Madrid: Vervuert/Iberoamericana, 2009.

Klein, Naomi. “'Qué se vayan todos!' - that's the global backlash talkin”. The Guardian (6 febrero 2009). Web. 2 julio 2018.

Knaller, Susanne. "Die Zeit des Bildes. Die Zeit der Schrift". Visuelle Evidenæ: Fotografie im Reflex von Literatur und Film. Ed. Sabine Becker y Barbara Korte. Berlin/New York: de Gruyter, 2011. 75-95.

Kunz, Marco. "Manuel Vázquez Montalbáns Pseudo-Biographie des Generals Franco". Zur Repräsentation politischer Herrschaft und Körperlichkeit. Ed. Jan-Henrik Witthaus y Patrick Eser. Bielefeld: Transcript, 2016. 209-232.

Landaluce, Emilia y Ana María Ortiz. "Los hijos de la reconciliación”. El Mundo (17 julio 2016). Web. 2 julio 2018. 
Lederer, Erika. "Decidí hacerme cargo de la mierda que me tocó." Página 12 (24 de mayo de 2017). Web. 2 julio 2018.

Lipis, Guillermo (y Erika Lederer). "Mi padre fue el obstetra de la maternidad clandestina de Campo de Mayo y no lo perdono". Télam (24 mayo 2017). Web. 2 julio 2018.

Longoni, Ana. "Apenas, nada menos (en torno a 'Arqueología de la ausencia', de Lucila Quieto)". Memorias urbanas en diálogo: Berlín y Buenos Aires. Ed. Peter Birle, Vera Carnovale, Elke Gryglewski y Estela Schindel. Buenos Aires/Santiago de Chile: Buenos Libros, 2010. 277-287.

Manganas, Nicholas. Las dos Españas: Terror \& Crisis in Contemporary Spain. Brighton/Chicago: Sussex Academic Press, 2016.

Marfani, Gemma. "El ADN como trazador del parentesco genético. Su uso en la búsqueda e identificación de desaparecidos". Desapariciones forzadas de niños en Europa y Latinoamérica. Del convenio de la ONU a las búsquedas a través del ADN. Ed. María Casado y Juan José López Ortega. Barcelona: Universitat de Barcelona, 2015. 1528.

Martín-Arroyo, Javier. "Los restos de Lorca no están en la fosa de Alfacar". El País (18 diciembre 2009). Web. 2 julio 2018.

Panizza, Paola. "Biopolítica. Viaje por los desafíos que nos plantean HIJOS". MU 21: Que los parió. Cómo nos está marcando la generación HIJOS (2008-09): 7.

Pantoja, Julio. "Los Hijos, Tucumán veinte años después” (1996). Web. 2 julio 2018.

Paul, Gerhard. Bilder des Krieges. Krieg der Bilder. Die Visualisierung des modernen Krieges. Paderborn: Schöningh, 2004.

Pichler, Georg. Gegenwart der Vergangenheit: Die Kontroverse um Bürgerkerieg und Diktatur in Spanien. Zürich: Rotpunktverlag, 2013.

Piovani, Ignacio, Clara Ruvituso y Nikolaus Werz (Ed.). Transiciones, memorias e identidades en Europa y América Latina. Frankfurt am Main/Madrid: Vervuert/Iberoamericana, 2016.

Quieto, Lucila. Arqueología de la ausencia. Ensayo fotográfico (1999-2001) Buenos Aires: Casa Nova, 2011. Web. 2 julio 2018.

Riano, Peio H. "Somos muchos los hijos y los nietos de la Guerra Civil que no dejaremos que se olvide". Entrevista con Andrea Stefanoni. El Confidencial (18 julio 2015). Web. 2 julio 2018.

Ricœur, Paul. Histoire et vérité. Paris: Seuil, 1955.

Ruiz Torres, Pedro. "Los discursos de la memoria histórica en España". Generaciones y memoria de la represión franquista: Un balance de los movimientos por la memoria. Ed. Julio Aróstegui y Sergio Gálvez Biesca. Valencia: Universitat de Valencia, 2010. 39-74.

Sanz Esquerro, David. "Clima prebélico en televisión con España: ensayo de una guerra”. El Mundo (2016). Web. 2 julio 2018. 
Schindel, Estela. La desaparición a diario: Sociedad prensa y dictadura (1975-1978). Villa María: Eduvim, 2012.

Silva, Emilio. "Mi abuelo también fue un desaparecido". La Crónica de León (8 octubre 2000).

Silva, Emilio. Las Fosas de Franco: crónica de un desagravio. Madrid: Temas de Hoy, 2006.

S.n. "Mi padre el torturador. Hijas de genocidas argentinos marchan contra la dictadura". El Universal (4 junio 2017). Web. 2 julio 2018.

Soler Azorín, Laura. "Los niños robados en la ficción televisiva. Casos de Argentina y España". Historia y poètiques de la memoria: la violència política en la representació del franquisme. Ed. Gabriel Sansano, Isabel Marcillas Piquer, Juan-Boris Ruiz-Núñez. Alacant: Universitat d'Alacant, 2016. 467-479.

Sosa, Cecilia. "Humour and the descendants of the disappeared. Countersigning bloodline affiliations in post-dictorial Argentina." Journal of Romance Studies 13.3 (2013): 75-87.

Stefanoni, Andrea. La abuela civil española. Barceolona: Seix Barral, 2015.

Stoellger, Philipp. "Bild, Pathos und Vergebung. Ricœurs Phänomenologie der Erinnerung und ihr bildtheoretischer Hintergrund (mit Blick auf G. Didi-Hubermann)". Bezeugte Vergangenheit oder versöhnendes Vergessen. Ed. Burkhard Liebsch. Berlin: Akademie Verlag, 2010. 179-213.

Straccia, Jairo. "Es hija de Videla y tiene un simbólico Falcon verde". Perfil (7 septiembre 2013). Web. 2 julio 2018.

Svampa, Maristella. La sociedad excluyente. Argentina bajo el signo del neoliberalismo. Buenos Aires: Taurus, 2005.

Taylor, Diana. Disappearing acts. Spectacles of gender and nationalism in Argentina's Dirty 'War'. Durham: Duke University Press, 1997.

Taylor, Diana. The Archive and the Repertoire. Performing Cultural Memory in the Americas. Durham: Duke University Press, 2003.

Torres, Rafael. Desaparecidos de La Guerra de España (1936-?) Barcelona: RBA, 2005.

Trigo, Abril. "Entre la globalización de la memoria y las memorias de la gobalización (Apuntes)". Políticas de le memoria. Tensiones en la palabra y la imagen. Ed. Sandra Lorenzano y Ralph Buchenhorst. Buenos Aires: Gorla y Ciudad de México: Universidad del Claustro de Sor Juana, 2007. 403-427.

Trueba, David. Soldados de Salamina. España, 2003. Film.

von Tschilschke, Christian. "Zusammenwirken und Konkurrenz der Medien in der Erinnerung an den spanischen Bürgerkrieg: Soldados de Salamina als Roman und Film". Literaturen des Bürgerkriegs. Ed. Anja Bandau, Albrecht Buschmann e Isabella von Treskow. Berlin: trafo, 2008. 269-285.

Vázquez, Celeste. "La prensa y la dictadura: una estrecha relación bajo la lupa". La izquierda (23 marzo 2011). Web. 2 julio 2018. 
Vezzetti, Hugo. Pasado y Presente. Guerra, dictadura y sociedad en la Argentina. Buenos Aires: Siglo XXI, 2002.

Wildner, Ralph. "Soldados de Salamina und Verfilmung von David Trueba". Erinnern und Erzäblen. Der spanische Bürgerkrieg in der deutschen und spanischen Literatur und in den Bildmedien. Ed. Bettina Bannsch y Christiane Holm. Tübingen: Narr, 2005. 547562.

Yusta Rodrigo, Mercedes. "¿Memoria versus justicia’? La 'recuperación de la memoria histórica' en la España actual”. Amnis. Revue de civilisation contemporaine Europe/ Amériques 2 (2011) (Memorias de la Guerra Civil española: transmisión, reapropiación y uso, Europa-América Latina). Web. 2 julio 2018. 